\title{
Insider understanding of country development: a novel application of Optimal Control Theory and Data Envelopment Analysis for benchmarking performance of Chilean and Brazilian companies
}

\author{
Paulo Nocera ALVES JUNIOR, Isotilia COSTA MELO, Daisy REBELATTO \\ University of São Paulo, Brazil \\ Wilfredo F. YUSHIMITO, Jorge Pereira GUDE \\ Universidad Adolfo Ibáñez, Chile
}

\begin{abstract}
:
Aim: If companies manage their inventory inefficiently, inventory costs can increase significantly due to shortages, overstocking, and risks. Thus, inventory management is critical for company's success which, in turn, impacts on countries' development. This paper aims to investigate the efficiency of inventory control systems of companies from Brazil and Chile through Optimal Control Theory (OCT) and Data Envelopment Analysis (DEA).
\end{abstract}

Design/Research methods: Data was collected from Chilean and Brazilian companies covering different industries in which both countries are mostly dependent (commerce, mining, nonmetallic minerals, fishing and agriculture). Then a new approach using OCT and DEA is applied for dealing with inventory, production, and demand in a Dynamic DEA model to benchmark these companies' production-inventory systems.

Conclusions/findings: The results allowed the identification of efficient companies among evaluated industries. Such companies are related mainly to Brazilian commerce and Chilean exports. Based on the findings, it was possible to identify patterns and relationship among companies and its inventory management.

Originality/value of the article: This paper fills a gap in studies including demand, production, and inventory in Dynamic DEA by using OCT to forewarn unrealistic results and observing companies' behavior. Besides that, this approach is particularly useful for developing countries in this context, determining the benchmarks for the most inefficient firms in each sector.

Correspondence address: Paulo Nocera Alves Junior, University of Sao Paulo, Brazil. E-mail: pnalvesjr@usp.br

Received: 30.09.2017, Revised: 20.01.2017, Revised: 20.11.2018, Accepted: 02.01.2019

doi: http://dx.doi.org/10.29015/cerem.578 
Implications of the research: The results show (1) which companies should focus more on improving inventory management, (2) which companies should be used as benchmarks, and (3) it highlights the reasons of different performance of companies in each country.

Limitations of the research: For future research, it is suggested including variables and analysis of social and environmental impacts. The use of more detailed sector classification is recommended.

Keywords: Keywords: Data Envelopment Analysis (DEA), Optimal Control Theory (OCT), Dynamic Efficiency, Developing Countries, Inventory Control, Production-Inventory System, Benchmarking, Best Practices.

JEL: L21, M21, L25

\section{Introduction}

Chile and Brazil are Latin American countries, colonized by Iberic countries (respectively, Spain and Portugal). Both faced political regimes at the beginning of the 20th century in which the dominant legislator controlled the executive through quasi-parliamentary mechanisms. The system was transformed in a way that the executive became the most powerful branch of government, Chile from 1924 until 1932 (Portales 2015) and Brazil from 1930 until 1945 (Lira Neto 2013). Both countries also had right-conservative dictatorships at the end of the same century, Chile from 1973 until 1990 and Brazil from 1964 until 1989, which impacted in their development in subsequent years (Fico 2008).

According to the World Bank (2016a), Brazil is currently facing a severe recession. The country's growth rate has slowed since the beginning of this decade, plunging from an annual growth rate of $4.5 \%$ between 2006 and 2010 to an average of $2.1 \%$ between 2011 and 2014. The unemployment rate in Brazil reached 10.9\% in the first quarter of 2016. Although the conditions for commodity-exporting countries is expected to be favourable in 2018 (because of the increase in demand), the Brazilian economy is not expected to efficiently follow it. The economy should weakly and slowly recover, and the World Bank expects unemployment to gradually reduce only by the end of 2018 (World Bank 2016a). at the same time, inflation is expected to remain under control (4.5\%) in 2017, but inequality will remain high.

On the other hand, in accordance with the same institution (World Bank 2016b), Chile has been one of the fastest growing economies in Latin America in the last 
decade. After the peak observed between 2011 and 2012 (15.30\%), the Chilean economy decelerated in 2014, with a growth of $1.9 \%$, and in 2015, a growth of $2.1 \%$ due to the reduction of both copper prices and domestic consumption. At the same time, unemployment has risen slightly from 5.7\% in 2013 to $5.8 \%$ in 2016. The Organization for Economic Cooperation and Development (OECD 2017a, 2017b), states that the Chilean economy is expected to grow 2.8\% in 2018, due to the improvement of the external demand and an increase of investments, reflecting more accommodative financial conditions.

Both economies are heavily dependent on exports (mining, agriculture, and livestock). Chile's exports include refined copper (23\% of the trade balance), copper ore $(21 \%)$, sulphates $(3.9 \%)$, grapes $(2.4 \%)$, fish fillets $(3.3 \%)$, wine $(2.5 \%)$, frozen fish (2.2\%), apples (1.3\%), and wood (1.3\%), among others (OEC 2016b). Brazil's exports include iron ore (12\%), soy (10\%), crude oil (7.2\%), raw sugar (4.3\%), pork (3.2\%), soy meat $(3.2 \%)$, coffee $(2.7 \%)$, sulphates $(2.5 \%)$, frozen beef $(2.1 \%)$, and semi-finished iron ore (1.1\%), among others (OEC 2016a). However, the Observatory of Economic Complexity (OEC 2016b, 2017a) points Chile as the 44th largest export economy in the world and Brazil as the 32nd, a small difference considering that the Chilean population corresponds to $8.79 \%$ of the Brazilian population, and its territorial extension corresponds to $8.88 \%$ of the Brazilian. To some extent, this is an indicator that Chile is proving to be more efficient in its exports.

Considering that conditions in both countries are similar, but the economic growth and the exports are distinct, this paper seeks to investigate whether there is also divergence in the efficiency of the open capital companies from exporting sectors (commerce, mining, nonmetallic minerals, fishing, and agriculture) in controlling their inventory systems. Inventory control is the practice of controlling the orders, the storage in warehouses, and the use of components that an enterprise uses for the products they sell. In developing economies, such as Chile and Brazil that strongly rely on commodity prices, inventories can seriously impact the economic performance. Hochman et al. (2011), for instance, investigated the increase of food commodity prices from 2001 until 2009 and concluded that when inventory impact is not taken into account in oversight of commodities price 
inflation, the impact of other factors (such as speculation, trade policy, and weather shocks) are probably overestimated.

Thus, measuring the efficiency of the inventory control system might be key in the performance of the economy. In doing so, the present paper proposes and applies a dynamic data envelopment analysis (DDEA) model integrated with optimal control theory (OCT), a variation of the model of Sengupta (1999). A justification for the use of a Dynamic DEA instead of a static one is because the development of countries is not static, it is always in evolution and changes over time.

Moreover, Fallah-Fini et al. (2014) reviews the state-of-art in dynamic models and points to inventories as one of the five most common factors attributed to the temporal interdependence. In addition, a recognized issue related to DEA and efficiency is the relationship between demand and production in time. The incorporation of this issue is already usual for static models though may be considered an innovation in literature for dynamic models. The application for comparing companies by sector in similar countries jointly (developing economies in Latin America) and for determining intrinsic reasons that may be influenced by the divergences in national performance is also a novelty in the literature. Although the impact of inventory systems for food commodity-prices has been already demonstrated (Hochman et al. 2011), this paper is also innovative in investigating the inventory control systems of non-alimentary commodities. Moreover, this paper is also aimed to investigate whether this contrast could be related to the difference in each country's performance, and to determine what are the benchmarks for the most inefficient firms in each sector.

\section{Literature review}

Effective inventory management is critical to a company's success. In general, a business spends more than a quarter of its budget just in inventory costs, and those that manage their inventory ineffectively can spend considerably more, incurring unnecessary costs, lower profits, and even increased the risk of bankruptcy. In this section, a review of inventory control models and efficiency benchmarking methods 
(namely DEA) are shown. Since the literature on both topics is extensive, the focus is only on the literature related to general aspects, which will be later used in the methodology.

Inventory control models can be used to support decision-making. For example, determining the order or production quantities, or determining the inventory level to be held. Optimal control theory (OCT) has been widely applied in inventory control, because it determines, for each analyzed period, the whole function in time or the discrete optimum value in a unique optimization operation. The drawback of OCT problems is that few of them can be solved analytically or with an analytical solution from Variational Calculus (Chilan, Conway 2015). In fact, the majority of the OCT models consist of unsolvable integrals or, when solvable, they require extensive computational effort and time. In this section, a review of OCT is included.

DEA has been applied using variables from production-inventory systems, especially DDEA using inventory as a factor of temporal interdependence that connects the periods of time. For these reasons, a review of DEA is also included.

\subsection{Optimal Control Theory (OCT)}

The OCT functions are based on a state variable dynamically dependent on the control and a control variable. For example, whether an inventory is a state variable (subject to time dependence) and production is the control variable, an OCT function could minimize the cost. In this case, the cost is the objective function to be minimized by the technique.

Sarimveis et al. (2008) provides a literature review on supply chain management problem, focused on recent mathematical tools emerging from the control literature. In real applications, the variation of inventory is understood as the result of the difference between the production, $\mathrm{P}$, and the demand, S. The authors describe the dynamics of an inventory system according to the Equation 1.

$$
\mathrm{I}_{\mathrm{i}}(\mathrm{t}+1)=\mathrm{P}(\mathrm{t})-\mathrm{S}(\mathrm{t})+\mathrm{I}_{\mathrm{i}}(\mathrm{t})
$$

Where $\mathrm{I}_{\mathrm{i}}(\mathrm{t})$ is the inventory level at the beginning of the period $t$. The order $\mathrm{P}(\mathrm{t})$ is the control or the manipulated variable and the demand $\mathrm{S}(\mathrm{t})$ is an exogenous disturbance. 
Equation 1 can also be described in terms of inventory level at the end of the period $t$ (since the final inventory level at the end of a period is equal to the initial inventory level of the beginning of the next period), as it can be seen in Equation 2.

$$
I(t)=P(t)-S(t)+I(t-1)
$$

Where $\mathrm{I}(\mathrm{t})$ is the final inventory level at the end of the period $t$ and the other variables are the same as in Equation 1.

Feichtinger and Harl (1985) develop a model for balancing the price policy and the production rate over a determined planning horizon. The optimal solution, consequently, involves production and inventory paths. Inventory levels are supposed to be nonnegatively constrained with its dynamics following the state differential equation (Equation 3). If the production exceeded demand, then the difference is added to the inventory. Otherwise, the excess demand is taken from the inventory.

$$
\frac{\text { aI }}{\text { at }}=\mathrm{P}(\mathrm{t})-\mathrm{S}(\mathrm{t})
$$

Where $\frac{\sigma I}{\sigma t} \cdot(t)$ is the inventory variation, $P(t)$ is the production rate, $S(t)$ is the demand rate. For Feichtinger and Harl (1985), the demand rate was also described in terms of the prices at time $t$.

In recent papers, Zhao et al. (2016) describes the same dynamics of Equation 3 though using the variables under other names, such as material quantity instead of the order $\mathrm{P}(\mathrm{t})$, or actual shipment instead of sales $\mathrm{S}(\mathrm{t})$. These variables can be considered as the classical production and demand ones. Even in the most recent publications, such as the stochastic optimal control model from Duan et al. (2018), used to maximize the profit in a pricing-production problem, based on Brownian Motion, the uses a similar dynamic to the one of Equation 3 though based on stochastic variables. Regarding the inventory, Duan et al. (2018) consider the following elements: the inventory level (units) at time $t$ (stable variable), the initial inventory (units), the inventory holding/shortage cost parameters and functions to be minimized.

Among the possible OCT approaches, one from Sethi and Thompson (2006) adopts an objective function, $\mathrm{J}$, that minimizes the production and the inventory 
costs at each period $t$ (Equation 1). This function is constrained by the condition of a differential state equation (because it is continuous-time control) that expresses the variation of inventory I. It uses the same inventory dynamics as Equation 4.

$$
\begin{aligned}
& \max J=\int_{0}^{T}-\left[C_{\mathrm{e}}(\mathrm{I}(\mathrm{t}))+\mathrm{C}_{\mathrm{p}}(\mathrm{P}(\mathrm{t}))\right] \mathrm{dt} \\
& \text { s.t.: }\left\{\begin{array}{c}
\dot{\mathrm{I}}(\mathrm{t})=\frac{\mathrm{aI}}{\mathrm{at}}=\mathrm{P}(\mathrm{t})-\mathrm{S}(\mathrm{t}) \\
\mathrm{I}(0)=\mathrm{I}_{0} \\
\mathrm{I}(\mathrm{T}) \geq \mathrm{I}_{\min } \\
\mathrm{P}_{\min } \leq \mathrm{P}(\mathrm{t}) \leq \mathrm{P}_{\max }
\end{array}\right.
\end{aligned}
$$

Where $\mathrm{T}$ is the last period of the analyzed time horizon. $\mathrm{C}_{\mathrm{e}}$ is the storage cost. $\mathrm{C}_{\mathrm{p}}$ is the production cost. $\mathrm{I}(\mathrm{t})$ is inventory function at time $\mathrm{t}$. $\mathrm{I} 0$ is the initial inventory of the first period $(t=0)$. I $(T)$ is the minimum inventory level desired in the last period $\mathrm{T}$ of the analyzed time horizon. $\mathrm{P}(\mathrm{t})$ is the production function at time t.

A variation of this model is considering a quadratic function with penalty, but for solving this problem in a simple and fast way, the first step was to transform the model into a linear discrete-time one, which can be solved by linear programming, i.e. as DEA. For this purpose, the integral function is substituted by the Riemann sum represented as $\int \mathrm{f}(\mathrm{t}) \mathrm{dt}=\sum \mathrm{f}(\mathrm{t}) \Delta \mathrm{t}$, with $\Delta \mathrm{t}=1$, and the differential is replaced by the difference equation $\frac{d f^{(}(t)}{d t}=\frac{\Delta f(t)}{\Delta t}$, with $\Delta t=1$ and $\Delta f(t)=f(t)-f(t-1)$, resulting in Equation 5:

$$
\begin{aligned}
& \max J=\sum_{0}^{T}-\left[C_{e}(I(t))+C_{p}(P(t))\right] \\
& \text { s.t. }\left\{\begin{array}{c}
P(t)=S(t)+I(t)-I(t-1) \\
I(0)=I_{0} \\
I(T) \geq I_{\min } \\
P_{\min } \leq P(t) \leq P_{\max }
\end{array}\right.
\end{aligned}
$$

Equation 5 uses the same inventory dynamics as Equation 4, but with discrete time (as Equation 2). The variational inventory difference constraint is also 
equivalent to Holt et al. (1960) and Thompson and Sethi (1980) that states I(t) - I(t1) $=\mathrm{P}(\mathrm{t})-\mathrm{S}(\mathrm{t})$ at time $\mathrm{t}$, from an initial inventory $\mathrm{I}(0)=\mathrm{I} 0$.

This model of Equation 5 minimizes costs through optimization of the control variable (production). Consequently, inventory (the state intermediate variable) will also be optimized. In the proposed model of the current research, a similar optimization will be used jointly with DEA constraints. The optimal results will be compared to the observed ones and this comparison is known as cost efficiency.

\subsection{Efficiencies and Data Envelopment Analysis (DEA)}

The calculation of efficiency measures based on the concepts of frontier production and cost functions began with Debreu (1951) and Farrell (1957). The second author proposed that efficiency can be classified into technical and allocative. Given certain inputs, technical efficiency represents the achievement of an ideal amount of outputs. The allocative efficiency represents the optimal use of inputs, given their prices. The overall cost efficiency is a multiplicative combination of technical and allocative efficiencies (Cooper et al. 2007).

The first Data Envelopment Analysis (DEA) model was CCR, created by (Charnes et al. 1978), an acronym of creators' family names. DEA computes the best non-arbitrary weights for each analyzing unit (called Decision-Making Unit DMU) and a single relative performance measure (relative efficiency) between 0 and 1 . The value 1 represents efficient units with $100 \%$ efficiency.

The CCR can be written in the form of multipliers form or its dual (envelopment form) (Charnes, Cooper 1962; Charnes et al. 1978; Tone 2001). The formulation of the envelopment form of CCR model oriented to inputs is presented in Equation 6.

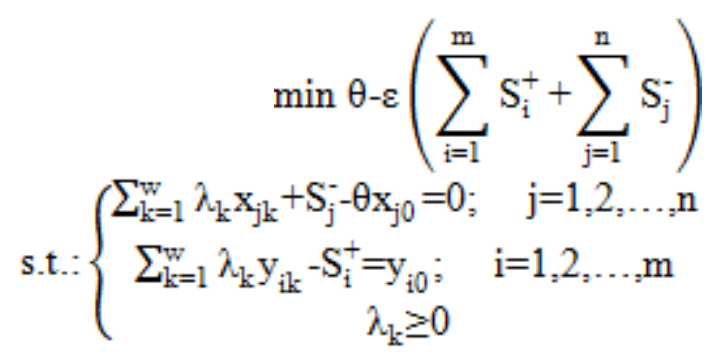


Where $\theta$ is the efficiency of the analyzed DMU. $\lambda_{\mathrm{k}}$ is the contribution of the kth DMU for the goal of the analyzed DMU. $y_{i 0}$ is the amount the ith output of the analyzed DMU. $\mathrm{x}_{\mathrm{j} 0}$ is the amount of the jth input of the analyzed DMU. $\mathrm{y}_{\mathrm{ik}}$ is the amount the ith output of the kth DMU. $\mathrm{x}_{\mathrm{jk}}$ is the amount of the jth input of the k-th DMU. $m$ is the number of outputs analyzed. $n$ is the number of inputs analyzed.

The envelopment form allows the visualization of the slacks of the variables and the direct identification of the benchmarks, instead of the visualization of the weights in multipliers form.

Cooper et al. (2007) states that whether the costs of inputs are known, it is possible to compute the cost efficiency through DEA, calculating the optimal minimal cost compared to the observed cost. The simplest minimization model is formulated based on an input-oriented model (Equation 7).

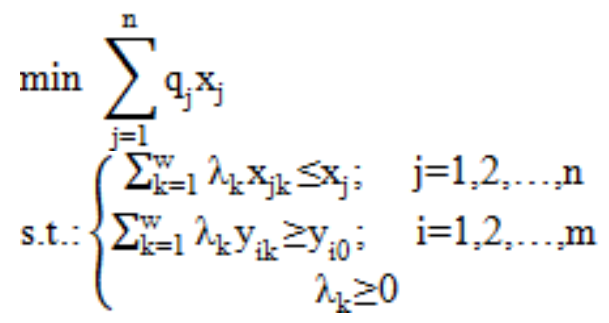

The cost efficiency $(\theta$ ce) is calculated in Equation 8:

$\theta_{c e}=\frac{\sum_{j=1}^{n} q_{j} x_{j}^{*}}{\sum_{j=1}^{n} q_{j} x_{j 0}}$

Where $x_{j}^{*}$ is the optimum amount of ith input. $x_{j 0}$ is the observed amount of ith input. $\mathrm{q}_{\mathrm{j}}$ is the observed cost.

The main challenge of dynamic models proposition is the calculation of efficiency using free intermediate variables as inputs or outputs depending on the time period because it can lead to a fail result, which may not represent what happens in practice and it could not be used to improve the system (Hatefi et al. 2009; Zhu 2014). For inventory control systems, calculating technical efficiency considering inventory as a free intermediate measure will possibly lead to the maximum efficiency (100\%) for all DMUs because the relationship among variables (demand + final inventory)/(production + initial inventory) is constant and equal to 
1. The combination of equal weights will, consequently, lead to maximum efficiency.

The proposed solution for this problem is an allocative model, i.e., a model where the objective function is constructed on the basis of costs so that the relationship among variables is not constant. The objective function is similar to the OCT model in Thompson and Sethi (1980) (without penalty) and the dynamic variational DEA (DDEA) of Sengupta (1999), though with the constraints adapted to inventory control systems.

\subsection{Dynamic Data Envelopment Analysis (DDEA)}

Fallah-Fini et al. (2014) classifies the causes of interdependence between different periods of time as (i) production delay (in relation to the use of inputs); (ii) inventory; (iii) quasi-fixed factors; (iv) adjustment costs; and (v) incremental improvement of learning.

The model of Sengupta (1999) is variational and its incorporated dynamic behavior may be characterized by the rate of change of the variable over time. In other words, for example, a constraint in which one of the terms is a differential state equation used to describe a reduction or an increase of capital. The allocative model of Sengupta (1999) is represented in Equation 9.

$$
\begin{gathered}
\max J=\int_{0}^{T} \mathrm{e}^{-\mathrm{rt}}\left[\sum_{\mathrm{j}=1}^{\mathrm{n}-1} \mathrm{q}_{\mathrm{j}}(\mathrm{t}) \mathrm{x}_{\mathrm{j}}(\mathrm{t})+\mathrm{c}\left(\mathrm{z}_{\mathrm{n}}(\mathrm{t})\right)\right] \mathrm{dt} \\
\text { s.t. }\left\{\begin{array}{c}
\sum_{\mathrm{l}=1}^{z} \mathrm{x}_{\mathrm{jk}} \lambda_{\mathrm{k}}(\mathrm{t}) \leq \mathrm{x}_{\mathrm{j}}(\mathrm{t}), \quad \mathrm{j}=1,2, \ldots, \mathrm{n}-1 \\
\sum_{\mathrm{l}=1}^{z} \mathrm{x}_{\mathrm{nk}} \lambda_{\mathrm{k}}(\mathrm{t}) \leq \mathrm{Xn}(\mathrm{t}) \\
\sum_{\mathrm{k}=1}^{\mathrm{z}} \mathrm{y}_{\mathrm{ik}} \lambda_{\mathrm{k}}(\mathrm{t}) \geq \mathrm{Y}_{\mathrm{ik},} \quad \mathrm{i}=1,2, \ldots, \mathrm{m} \\
\sum_{\mathrm{lk}=1}^{z} \lambda_{\mathrm{k}}(\mathrm{t})=1 \\
\dot{\mathrm{x}}_{\mathrm{n}}(\mathrm{t})=\mathrm{z}_{\mathrm{n}}(\mathrm{t})-\delta \mathrm{x}_{\mathrm{n}}(\mathrm{t})
\end{array}\right.
\end{gathered}
$$

Where $\mathrm{T}$ is the last period of the analyzed time horizon. "e" ^ "-rt" is the discount factor. "c" ("z" _ " $n$ " ("t")) is the cost of the investment. "q" _ "j" ("t") is 
the price of capital input. " $x "$ _ " $j$ " ("t") is the capital input at time t. "q" _ "j" ("t") " $\mathrm{x}$ " _ " $\mathrm{j}$ " ("t") is the investment in durable goods in the process. " $\mathrm{x}$ " . " $\mathrm{n}$ " ("t") is the expansion of capital input (time derivative of capital input. " $z$ " _ " $n$ " (" $t$ ") is the gross investment. $\delta$ is the rate of the depreciation. " $\lambda$ " _ " $\mathrm{k}$ " (" $\mathrm{t}$ ") is the contribution of the kth DMU for the goal of the analyzed DMU at time $t$.

Similarly to HMSS model of optimal production planning developed by Holt et al. (1960), this objective function may be interpreted as adjustment costs, subject to constraints from DEA and state equation that represent the depreciation of capital (Sengupta 1999).

\section{Methodology}

\subsection{Problem setting}

The problem addressed is to evaluate the efficiency of Chilean and Brazilian companies including variables related to the production-inventory system. Figure 1 shows the structure of the dynamic system, with interactions among periods (the final inventory of a period is the initial inventory of the next period and its variation over time). While Figure 2 shows the same system, though without the interactions. The dynamic model captures the dynamic efficiencies, considering a more realistic measure of the interactions among periods, because, without this consideration, the same inventory would be accounted for more than one time.

In this dynamic case, the inventory is used as a free intermediate measure, and because of the behavior of inventory control systems, as.it can be seen in Figure 1, the final inventory of a period is used as an output of the period in analysis (it is desirable to have a minimum amount of inventory not to incur in lack of inventory or to not increase the risk of lack of a product) while the initial inventory of a period is equal to the final inventory of the last period and it is used as input of the period in analysis (although it commonly happens, it is undesirable if an inventory excess exists). 
Figure 1. Structure of the dynamic system

Period $t$

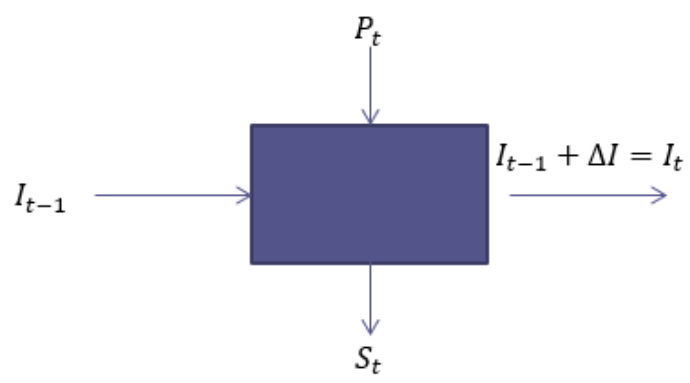

Period $t+1$

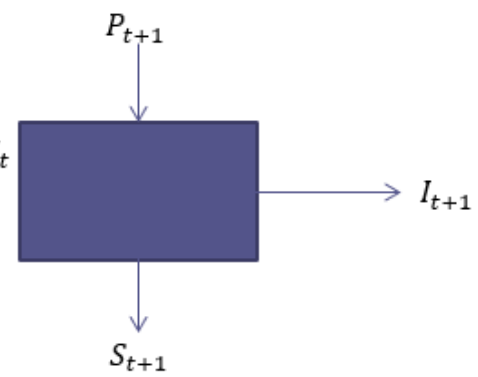

Figure 2. Structure of the system without interaction among the periods
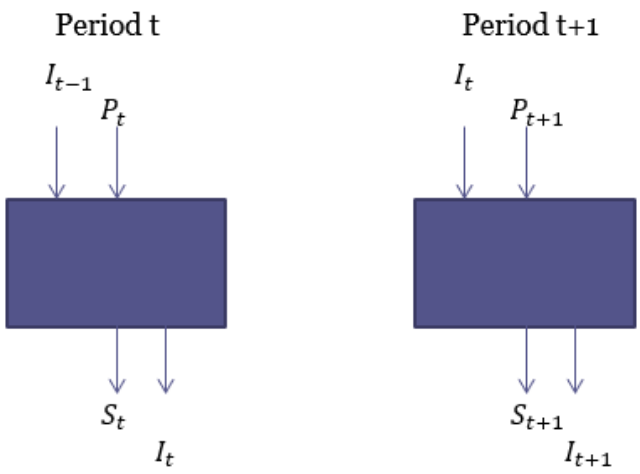

\subsection{Proposed model}

Before proposing the model based on DDEA and OCT, it is important to know how to solve these kinds of models. According to Gonzalez et al. (2015), some metaheuristics leads to unsatisfactory solutions when solving DEA problems, and Alves Junior and Cari (2017) state that solving a nonlinear OCT problems without a good initial guess of the solution or even with some metaheuristics, as genetic algorithm, takes an unworkable time to be solved.

Hence, it will be taken the recommendation to solve OCT problems transforming the problem into a linear discrete-time OCT problem to solve sums and differences with linear programming instead of integrals and differentials in a 
nonlinear optimization. And then it was mixed to DEA constraints. According to Sarimveis et al. (2008), integrals and derivative elements complicate the tuning excessively, this may be one of the reasons this approach does not receive the attention of the literature, mainly the continuous-time OCT problems.

The proposed model follows the constraints and a function comparable to the well-known standard allocative DEA, consider minimizing costs, adding inventories (initial and final), and production costs of the analyzed period. The objective function of the model is similar to the models previously mentioned (Holt et al. 1960; Thompson, Sethi 1980; Sengupta 1999; Sethi, Thompson 2006), though summing jointly with other costs of inputs and intermediate measure whether this is the case of the study. Therefore, the general formulation of the proposed model for discrete time under Constant Returns to Scale (CRS) is in Equation 10.

$$
\begin{aligned}
& \min \\
& \sum_{\mathrm{t}=1}^{\mathrm{T}}\left[\sum_{\mathrm{j}=1}^{\mathrm{n}-1} \mathrm{Cx}_{\mathrm{j} 0}\left(\mathrm{t}, \mathrm{x}_{\mathrm{j} 0}(\mathrm{t})\right)+\sum_{\mathrm{h}=1}^{\mathrm{I}-1} \mathrm{Cz}_{\mathrm{h} 0}\left(\mathrm{t}, \mathrm{z}_{\mathrm{h} 0}(\mathrm{t})\right)+\mathrm{Cx}_{\mathrm{n} 0}\left(\mathrm{t}, \mathrm{x}_{\mathrm{n} 0}(\mathrm{t})\right)+\mathrm{Cz}_{10}\left(\mathrm{t}, \mathrm{z}_{10}(\mathrm{t})\right)\right]
\end{aligned}
$$

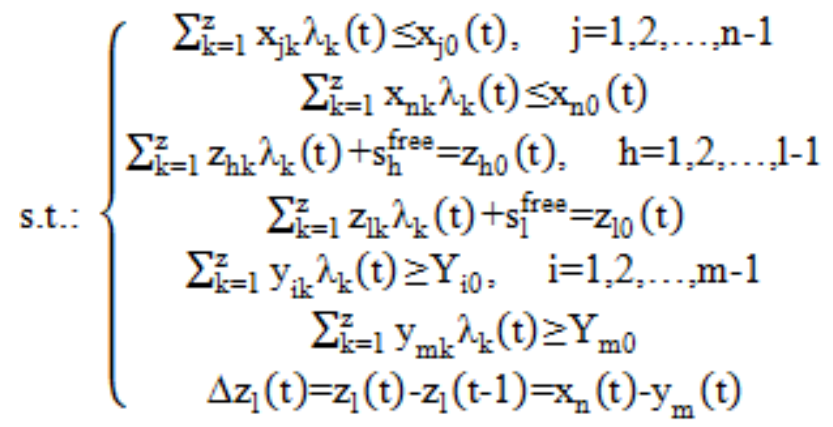

Where this objective cost function $\mathbf{J}$ of the DMU0 under analysis may be interpreted as follows: $\mathrm{T}$ is the last period of the analyzed time horizon, $\mathrm{Cx}_{\mathrm{j}}\left(\mathrm{t}, \mathrm{x}_{\mathrm{j}}(\mathrm{t})\right)$ is the cost of the $\mathrm{i}$-th input, $\mathrm{x}_{\mathrm{j}}(\mathrm{t})$ is the projection quantity of the $\mathrm{i}$-th input, $\mathrm{Cz}_{\mathrm{h}}\left(\mathrm{t}, \mathrm{z}_{\mathrm{h}}(\mathrm{t})\right)$ is the cost of the $\mathrm{h}$-th intermediate measure, $\mathrm{z}_{\mathrm{h}}(\mathrm{t})$ is the projection quantity of the $h$-th intermediate measure, $x_{n}(t)$ is the quantity of the main control variable (e.g. production in the production-inventory system), $\mathrm{z}_{1}(\mathrm{t})$ is 
the quantity of the main state variable (e.g. inventory in the production-inventory system), $\mathrm{Cx}_{\mathrm{n}}\left(\mathrm{t}, \mathrm{x}_{\mathrm{n}}(\mathrm{t})\right)$ is the cost of the control variable (e.g. production cost in the production-inventory system), $\mathrm{Cz}_{1}\left(\mathrm{t}_{\mathrm{z}_{1}}(\mathrm{t})\right)$ is the cost of the state variable (e.g. inventory cost in the production-inventory system).

In the constraints, $\lambda_{\mathrm{k}}(\mathrm{t})$ is the contribution of the k-th DMU to the DMU0 under analysis, $\mathrm{x}_{\mathrm{jk}}$ is the $\mathrm{j}$-th input of the k-th DMU, $\mathrm{y}_{\mathrm{ik}}$ is the $\mathrm{i}$-th output of the k-th DMU, $\mathrm{z}_{\mathrm{hk}}$ is the $\mathrm{h}$-th intermediate measure of the $\mathrm{k}$-th DMU, $\mathrm{x}_{\text {nk }}$ is the main control input of the k-th DMU, $y_{n k}$ is the main exogenous output of the k-th DMU (e.g. demand in the production-inventory system), $\mathbf{z}_{\mathrm{ll}}$ is the main state intermediate measure of the k-th DMU, $\mathrm{s}_{\mathrm{h}}^{\text {frea }}$ and $\mathrm{s}_{1}^{\text {frea }}$ are slacks denoting link deviation (it can be assumed equal to 0 in the case of fix intermediate measures), and $\Delta z_{1}(t)$ is the variation of the main state intermediate measure in relation to the time $t$ (e.g. variation of the inventory in the production-inventory system).

By means of adding the link and the equivalent constraints of Tone and Tsutsui (2014), since we are considering the inventory $\mathbf{z}_{\mathbb{l k t}}$ as initial and final of the period $t$, it can be split into $z_{\mathbb{l k t}}^{+}=z_{\mathbb{l k}(t)}$, and $z_{\mathbb{l l k t}^{-}}^{-}=z_{\mathbb{l k}(t-1)}$ and them the equivalence $z_{\mathbb{l k}(t-1)}^{+}=z_{\mathbb{l k k} \cdot}^{-}$. The link constraint can also be split into $\sum_{\mathrm{k}=1}^{z} \mathrm{I}_{\mathrm{kt}}^{+} \lambda_{\mathrm{ktt}}+\mathrm{s}_{\mathrm{t}}^{+ \text {frea }}=\mathrm{z}^{+}{ }_{10 \mathrm{t}}$, for $\mathrm{t}=1, \ldots, \mathrm{T}$, and $\sum_{\mathrm{k}=1}^{\mathrm{z}} \mathrm{I}_{\mathrm{kt}}^{-\lambda_{\mathrm{ktt}}}+\mathrm{s}_{\mathrm{t}}^{-\mathrm{frea}}=\mathrm{z}_{\mathrm{l0t}}^{-}$, for $\mathrm{t}=1, \ldots, \mathrm{T}$. And the variational constraint of the model is the variation of inventory of the discrete model: $\mathrm{x}_{\mathrm{nOt}}-\mathrm{z}^{+}{ }_{10 \mathrm{t}}^{+}+\mathrm{z}_{\mathrm{I0t}}^{-}=\mathrm{Y}_{\mathrm{m01}}$.

With this formulation, it is possible to consider future demand in advance to minimize the costs. Once it is influenced by demand forecasting. Assuming that the best demand forecasting was made when managing the inventory, it is possible to check if the control could be improved without changing the forecasting, by imposing a projection constraint $\mathrm{x}_{\mathrm{n} 0 \mathrm{t}} \leq \mathrm{P}_{\mathrm{Ot}}$. This kind of constraint was exposed by Zhu (2009). So the cost of each period should be lower than the observed cost, indicating that if the company keeps the same management (without foretaste of costs to have lower costs in the desired period under analysis), it could have reduced its costs, so the control could be improved anyway, without considering future demand in advance to check only the excess of production (management/control was not efficient). 
The model also has the Initial value constraint: $\mathrm{z}_{100}^{-}=\mathrm{I}_{0}$. So $\mathrm{z}_{10 \mathrm{t}}^{-}$is not considered in the objective function, because $\mathrm{z}_{100}^{-}$is constant, and for $\mathrm{t}=1, \ldots, \mathrm{T}$ (middle periods) it is equal to the $\mathbf{z}_{10 t}^{+}$.

Given that DEA models are linear and it is common to use discrete data, the linear discrete-time model is proposed to be applied to inventory control systems. For this application, with all variables and costs estimated, it is possible to minimize the objective function. Considering only variable from the production-inventory system, and not a general DEA model, the objective function is the sum of the optimal projection of inventory and production costs of the system that will lead to the cost efficiency when compared to the observed costs (the projections are expressed as $\left.\mathrm{z}_{\mathrm{lt}}^{+}, \mathrm{x}_{\mathrm{nt}}\right)$ : $\min \sum_{\mathrm{t}=1}^{\mathrm{T}}\left[\mathrm{Cf}_{0 \mathrm{t}} \mathrm{z}_{10 \mathrm{t}}^{+}+\mathrm{Cp}_{0 \mathrm{t}} \mathrm{x}_{\mathrm{n} 0 \mathrm{t}}\right]$.

After computing the optimal cost of the system, $\mathrm{C}_{\text {system }}^{*}=\sum_{\mathrm{t}=0}^{\mathrm{T}}\left[\mathrm{Cf}_{0 \mathrm{t}} \mathrm{z}_{10 \mathrm{t}}^{*}+\mathrm{Cp}_{0 \mathrm{t}} \mathrm{x}_{\mathrm{nOt}}^{*}\right]$, it is compared to the real cost $\mathrm{C}_{\text {system }}=\sum_{\mathrm{t}=0}^{\mathrm{T}}\left[\mathrm{Cf}_{0 \mathrm{t}} \mathrm{I}_{0 \mathrm{t}}+\mathrm{Cp}_{\mathrm{Ot}} \mathrm{P}_{0 \mathrm{t}}\right]$ to calculate the cost efficiency of the system in Equation 11.

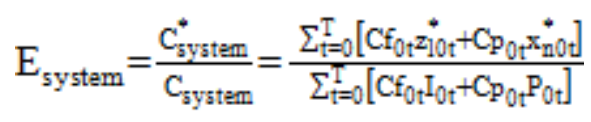

$\mathrm{E}_{\text {system }}$ represents the efficiency of a dynamic system structured in Figure 1. $\mathrm{E}_{\mathrm{t}}$ represents the efficiency of the same system, though without interaction among the periods because it is the efficiency of the period, as structured in Figure 2.

These optimal costs of the system and per period can be expressed as a projection of the actual costs to the optimal frontier considering the efficiencies (Equations 12 and 13).

$$
\mathrm{C}_{\text {system }}^{*}=\mathrm{E}_{\text {system }} \cdot \mathrm{C}_{\text {system }}
$$

$$
\mathrm{C}_{\mathrm{t}}^{*}=\mathrm{E}_{\mathrm{t}} \cdot \mathrm{C}_{\mathrm{t}}
$$

The software MATLAB was used for the calculation of functions, variables, parameters, and coefficients, executing the model with the incorporation of the characteristics of the discrete-time production-inventory model of Sethi and 
Thompson (2006) and the difference variational constraint describing the relationship between the demand, production, and inventory variables.

\subsection{Extensions and further development of the model}

In further developments of the model, some characteristics can be assumed, e.g. considering Variable Returns to Scale (VRS) developed by Banker et al. (1984). Since the DEA finds optimal values based on the data from the benchmark DMUs, some constraints can be dropped depending on the desired analysis to be performed, e.g. initial value of the inventory considered in Sethi and Thompson (2006). For example, the initial value constraint $\mathrm{z}_{01}^{-\mathrm{p}}=\mathrm{I}_{0}$ it is not always necessary in this DEAOCT model, though it is necessary for pure OCT models. The initial value constraint is in Equation 14.

$$
\mathrm{z}_{01}^{-\mathrm{p}}=\mathrm{I}_{0}
$$

In certain circumstances, the initial inventory level of the first-period $t$ may be considered. If the DMU starts with an excess of initial inventory, possibly due to the inefficiency of periods prior to the analysed ones, the DEA model can classify this DMU as inefficient (due to a cascade effect), despite efficient practices in the analysed periods. If it is desired to measure the management and control efficiency exclusively during the analysed time horizon (without a possible cascade effect), this constraint needs to be considered, since the DMU can present an efficient management over the analysed time horizon, overcoming a possible mismanagement of previous periods. If the DMU is efficient considering the initial, though inefficient without considering it, it may be recommended that the DMU optimize its inventory levels, if necessary by promoting / liquidating the old inventory (in case of excess inventory) or analysing the supply policies (in case of inventory shortage), to verify if it was a punctual inefficiency and its causes (delay in resupply, imprecise forecasting, limited capacity, etc.).

It is important to note that this kind of difference in results was observed in a simulated example, though it does not happen in most of the real data. In this paper, the results in terms of the status of the DMUs (if it was efficient or not) was the same to all DMUs using or dropping the initial value constraint. 
The other type of constraint that can also be considered in the models is the constraint that leads to Variable Returns to Scale (VRS) since an increase in productions and inventories not always leads to a proportional and constant increase in demand. The VRS constraint is in Equation 15.

$$
\sum_{\mathrm{k}=1}^{z} \lambda_{\mathrm{k}}(\mathrm{t})=1
$$

Examples of DMUs where it is expected the VRS behaviors in the inventory control system are large supermarkets or department stores that need to stock a wide variety of all types of products, although lateness demand ends up being put on sale and it is sold at a lower price. Some of these DMUs can be efficient if the VRS assumption is considered. The list of efficient DMUs under the VRS assumption is shown in Table 4 (Appendix A).

\section{Sample data and research variables}

The quarterly data of Brazilian and Chilean companies were retrieved in Economática databank, considering the period from the fourth quarter of 2010 (to calculate the average cost of inventory and use the initial inventory in the next quarter) until the first quarter of 2016. The choice of period is an account of the fact that Brazil mandatorily adopted International Financial Reporting Standards (IFRS) to emit financial statements in 2010, making the comparison between both countries possible. The means and the standard deviations of each variable per sector are shown in Table 5 (Appendix B).

The goal of the study is to analyze the inventory control system of the maximum possible number of companies from Brazil and Chile, but some sectors were excluded from the analysis. Specifically, the sectors of finance and insurance, software, and data, fund, as well as the sectors related to the provision of services, such as electric energy, transport, telecommunications, and the category others were removed. DMUs using a different accounting method other than the IFRS or containing negative data, data equal to zero, or missing information were also excluded. After that, if a sector does not have at least one representative DMU of each country, it was excluded too. It was also excluded 4 sectors (Electronics, 
Industrial Machines, Textile, and Vehicles and Parts) in that condition because it is not possible to make comparisons between countries. As a result, it was analyzed 141 companies ( 82 from Brazil and 59 from Chile) from 10 sectors.

According to the variable classification of Tone and Tsutsui (2014), inventory is an intermediate measure of free type, demand is an output, and production is an input. Once the intermediate variable is free, it is split into two variables: (i) initial inventory of period t-1 (input link); and (ii) final inventory of period t (output link). The descriptions of the variables and parameters used in the DDEA-OCT model are shown in Błąd! Nie można odnaleźć źródła odwołania.Table 1.

\section{Table 1. Description of functions, variables and parameters}

\begin{tabular}{|c|c|c|c|}
\hline $\begin{array}{c}\text { Functions, } \\
\text { variables, and } \\
\text { parameters }\end{array}$ & Description & $\begin{array}{c}\text { Functions, variables, } \\
\text { and parameters }\end{array}$ & Description \\
\hline$J$ & $\begin{array}{l}\text { Objective function (cost } \\
\text { function) }\end{array}$ & $\mathbf{I}_{\mathbf{0}}$ & $\begin{array}{c}\text { Initial inventory } \\
\text { (inventory of period } 0 \text { at } \\
\text { time } 1 \text { ) }\end{array}$ \\
\hline$T$ & Time & $\mathbf{R}$ & Revenue \\
\hline$D$ & $\begin{array}{l}\text { Demand (exogenous } \\
\text { output) }\end{array}$ & $C_{p}$ & Unitary production cost \\
\hline $\boldsymbol{P}$ & Production (control input) & $\mathbf{C}_{\mathbf{f}}$ & $\begin{array}{c}\text { Unitary (final) inventory } \\
\text { cost }\end{array}$ \\
\hline$I(t)$ & $\begin{array}{c}\text { Inventory at } t \text { (state } \\
\text { intermediate variable) }\end{array}$ & $\mathbf{C}_{\mathbf{i}}$ & $\begin{array}{c}\text { Unitary (initial) inventory } \\
\text { cost }\end{array}$ \\
\hline$I^{+}$ & $\begin{array}{c}\text { Final inventory or } \\
\text { inventory at } t \text { (output } \\
\text { link) }\end{array}$ & $\mathbf{C}_{\mathbf{d}}$ & Sold production cost \\
\hline$I^{-}$ & $\begin{array}{c}\text { Initial inventory or } \\
\text { inventory at t-1 (input } \\
\text { link) }\end{array}$ & CPP & $\begin{array}{l}\text { Cost of period production } \\
\text { (or purchase) }\end{array}$ \\
\hline$\lambda(t)$ & $\begin{array}{l}\text { Contribution of DMUs to } \\
\text { the analyzed DMU }\end{array}$ & CEF & Cost of final inventory \\
\hline$S^{+}$ & $\begin{array}{c}\text { Output slack (or output } \\
\text { link slack) }\end{array}$ & CEI & Cost of initial inventory \\
\hline$S^{-}$ & $\begin{array}{c}\text { Input slack (or input link } \\
\text { slack) }\end{array}$ & COGS & Cost of goods sold \\
\hline
\end{tabular}

The chosen variables can be justified with the papers presented in Section 2 (literature review). Some variables are common in DEA literature $\left(\lambda(t), \mathrm{S}^{+}\right.$, and $\mathrm{S}^{-}$). 
The unit costs $\left(\mathrm{C}_{\mathrm{p}}, \mathrm{C}_{\mathrm{f}}, \mathrm{C}_{\mathrm{i}}\right.$, and $\left.\mathrm{C}_{\mathrm{d}}\right)$ and quantities $\left(\mathrm{D}, \mathrm{P}, \mathrm{I}^{+}, \mathrm{I}^{-}\right)$variables can be justified with the OCT literature and because of the research problem based on the issue exposed in the paper of Fallah-Fini et al. (2014). Total costs variables (CPP, CEF, CEI, and COGS) and Revenue were chosen (due to availability in accounting reports, as it is described below) to estimate the other values.

Due to the availability of accounting data, for this paper it was considered the values of revenue, cost of goods sold (COGS) and costs of inventories (CE), which can be split into the cost of final inventory (CEF) and the cost of initial inventory (CEI).

The COGS formula described in Doupnik et al. (2013) was applied to calculate the cost of period purchase (CPP), in the case of commerce, or the cost of period production (CPP) in industrial sectors as follows: CPP = COGS + CEF-CEI

These costs are decomposed in average unit costs and quantities, as in Alves Junior and Cari (2017) and stated in Equation 16.

$$
\text { Cost }=\text { Unitary Cost } * \text { Quantity }
$$

And the relative cost $(\mathrm{CR})$ to generate $\$ 1.00$ of revenue $(\mathrm{R}=1)$ was used as a financial measure. Therefore, unit costs and relative quantities were estimated to obtain all the necessary values from the accounting data in the reports. The CR can be calculated according to Equation 17.

$$
\mathrm{CR}=\mathrm{COGS} / \text { revenue }
$$

For engineering, storage holding costs can be estimated based on the average inventory of the period $\mathrm{C}\left(\mathrm{I}^{-}+\mathrm{I}^{+}\right) / 2$, e.g., whether the inventory decreases at a constant rate from $I^{-}$to $I^{+}=0$, the average inventory is $I^{-} / 2$, and the annual holding cost is $\mathrm{C}_{\text {annual }}\left(\mathrm{I}^{-}+0\right) / 2$ (Stevenson 2012). Consequently, its sum is equivalent to the final and initial quantities of inventories, incurring average costs. Remember that the final inventory of a period is equal to the initial inventory for the next period. It was considered that the costs are proportional to the average $\mathrm{CR}$ to estimate $\mathrm{Cf}$ and $\mathrm{Ci}$ for intermediate periods (Equation 18).

$$
\mathrm{Cf}_{\mathrm{t}}=\frac{\left(\mathrm{Cd}_{\mathrm{t}}+\mathrm{Cd}_{\mathrm{t}+1}\right)}{2}, \mathrm{t}=1, \ldots, \mathrm{T} \text { and } \mathrm{Ci}_{\mathrm{t}}=\frac{\left(\mathrm{Cd}_{\mathrm{t}-1}+\mathrm{Cd}_{\mathrm{t}}\right)}{2}, \mathrm{t}=1, \ldots, \mathrm{T}
$$


When necessary, two extra periods can be used to calculate $\mathrm{Cd}_{0}$ and $\mathrm{Cd}_{\mathrm{t}+1}$ costs, though the analysis horizon is reduced by 2 periods (Alves Junior, Cari 2017). After calculating the storage costs, it is possible to obtain the values of the intermediate variables (final and initial inventories - Equation 19).

$$
\mathrm{I}^{+}=\frac{\mathrm{CEF}}{\mathrm{Cf}} \text { and } \mathrm{I}^{-}=\frac{\mathrm{CEI}}{\mathrm{Ci}}
$$

The values of outputs (demand D is proportional to revenue, and it is calculated similarly to I) and inputs (production), according to Equation 20.

$$
\mathrm{P}=\mathrm{D}+\mathrm{I}^{+}-\mathrm{I}^{-}
$$

The average unitary production cost can be calculated as in Equation 21.

$\mathrm{Cp}=\frac{\mathrm{CPP}}{\mathrm{P}}$

\section{Results and discussions: empirical application}

This topic will, firstly, present an observation on the correlations between efficiencies and inventory variations of inefficient DMUs. It was possible to observe that the variations of the inventory were not strongly nor significantly (positive or negative) correlated to the efficiencies (coefficient correlation between -0.0507 and 0.3295), except for the sector of mining (coefficient correlation of $-0,9227$ ), so not always a demand with less variation and consequently a stable inventory control leads to greater efficiency, even being easier to manage (except for the mining sector).

Following, it is presented general results, DDEA efficient results and overview the sectors of both countries comparatively.

\subsection{General results}

The model was applied to companies in each sector of both countries. Among the 141 analyzed companies, there were 29 efficient DMUs (20.57\% of total): 12 Chilean and 17 Brazilian firms (as it can be seen in Table 2). It was possible to find 
efficient cases from both countries in the sectors of food and beverage, paper and cellulose, and oil and gas.

Table 2. The most efficient companies using the proposed model

\begin{tabular}{|c|c|c|c|}
\hline Sector & Country & DMU & Efficiency \\
\hline \multirow[t]{2}{*}{$\begin{array}{l}\text { Agr. and } \\
\text { Fishing }\end{array}$} & Chile & Schwager & 1 \\
\hline & Chile & Viconto & 1 \\
\hline \multirow[t]{5}{*}{$\begin{array}{l}\text { Foods and } \\
\text { Beverages }\end{array}$} & Chile & $\begin{array}{l}\text { Concha y } \\
\text { Toro }\end{array}$ & 1 \\
\hline & Chile & Emiliana & 1 \\
\hline & Brazil & Josapar & 1 \\
\hline & Brazil & Minupar & 1 \\
\hline & Brazil & Tereos & 1 \\
\hline \multirow[t]{2}{*}{ Commerce } & Brazil & Battistella & 1 \\
\hline & Brazil & $\begin{array}{c}\text { BR } \\
\text { Pharma } \\
\end{array}$ & 1 \\
\hline \multirow[t]{3}{*}{ Construction } & Brazil & Azevedo & 1 \\
\hline & Brazil & $\begin{array}{l}\text { Lix da } \\
\text { Cunha }\end{array}$ & 1 \\
\hline & Brazil & PDG Realt & 1 \\
\hline \multirow[t]{3}{*}{ Mining } & Chile & Pucobre & 1 \\
\hline & Chile & Soprocal & 1 \\
\hline & Chile & Sqm & 1 \\
\hline \multirow[t]{3}{*}{$\begin{array}{c}\text { Nonmetallic } \\
\text { minerals }\end{array}$} & Chile & Cementos & 1 \\
\hline & Chile & Cristales & 1 \\
\hline & Chile & Polpaico & 1 \\
\hline \multirow[t]{3}{*}{$\begin{array}{l}\text { Paper and } \\
\text { Cellulose }\end{array}$} & Chile & $\begin{array}{c}\text { Celulosa } \\
\text { Arauco }\end{array}$ & 1 \\
\hline & Brazil & Celul Irani & 1 \\
\hline & Brazil & $\begin{array}{c}\text { Santher } \\
\text { Fab de } \\
\text { Papel Sta } \\
\text { Terezinha }\end{array}$ & 1 \\
\hline \multirow[t]{2}{*}{$\begin{array}{l}\text { Oil and } \\
\text { Gas }\end{array}$} & Chile & Gasco & 1 \\
\hline & Brazil & CEG & 1 \\
\hline \multirow[t]{2}{*}{ Chemical } & Brazil & Cristal & 1 \\
\hline & Brazil & Fer Heringer & 1 \\
\hline
\end{tabular}


Table 2. Cont. ...

\begin{tabular}{|l|c|l|c|}
\hline & Brazil & Ultrapar & 1 \\
\hline $\begin{array}{l}\text { Steel and } \\
\text { Metallurgical }\end{array}$ & Brazil & Ferbasa & 1 \\
\hline & Brazil & Iguaçu & 1 \\
\hline & Brazil & Paranapanema & 1 \\
\hline
\end{tabular}

Considering the extensions and further development of the model (Section 3.3. of this paper), the results in terms of status of the DMUs (if it was efficient or not) were the same to all DMUs, using or dropping the initial value constraint, so the list of efficient DMUs for the first extension was the same as shown in Table 2.

Table 3. Standard deviation, average efficiencies, and number of efficient companies per sector

\begin{tabular}{|l|c|c|c|c|c|c|c|c|c|}
\hline \multirow{2}{*}{ Sectors } & \multicolumn{3}{|c|}{ Average Efficiencies } & \multicolumn{3}{c|}{$\begin{array}{c}\text { Standard Deviation of } \\
\text { efficiencies }\end{array}$} & \multicolumn{3}{|c|}{$\begin{array}{c}\text { Number of Efficient } \\
\text { Companies }\end{array}$} \\
\hline Sectors & General & BR & CL & General & BR & CL & General & BR & CL \\
\hline $\begin{array}{l}\text { Agriculture } \\
\text { \& Fishing }\end{array}$ & 0.9628 & 0.9710 & 0.9623 & 0.0467 & 0.0000 & 0.0483 & 2 & 0 & 2 \\
\hline $\begin{array}{l}\text { Food \& } \\
\text { Beverage }\end{array}$ & 0.9630 & 0.9604 & 0.9660 & 0.0546 & 0.0609 & 0.0489 & 5 & 3 & 2 \\
\hline Commerce & 0.9408 & 0.9594 & 0.9055 & 0.0583 & 0.0438 & 0.0679 & 2 & 2 & 0 \\
\hline Construction & 0.9232 & 0.9293 & 0.8991 & 0.0820 & 0.0828 & 0.0909 & 3 & 3 & 0 \\
\hline Mining & 0.9986 & 0.9965 & 1.0000 & 0.0025 & 0.0030 & 0.0000 & 3 & 0 & 3 \\
\hline $\begin{array}{l}\text { Non-Metallic } \\
\text { Minerals }\end{array}$ & 0.9899 & 0.9797 & 1.0000 & 0.0139 & 0.0133 & 0.0000 & 3 & 0 & 3 \\
\hline $\begin{array}{l}\text { Paper \& } \\
\text { Cellulose }\end{array}$ & 0.9849 & 0.9882 & 0.9766 & 0.0196 & 0.0159 & 0.0331 & 3 & 2 & 1 \\
\hline Oil \& Gas & 0.9826 & 0.9908 & 0.9724 & 0.0283 & 0.0092 & 0.0422 & 2 & 1 & 1 \\
\hline Chemical & 0.9789 & 0.9867 & 0.9653 & 0.0276 & 0.0195 & 0.0372 & 3 & 3 & 0 \\
\hline $\begin{array}{l}\text { Steelworks } \\
\text { \& } \\
\text { Metallurgical }\end{array}$ & 0.9647 & 0.9746 & 0.9330 & 0.0478 & 0.0285 & 0.0820 & 3 & 3 & 0 \\
\hline
\end{tabular}

$\mathrm{BR}=$ Brazil, $\mathrm{CL}=$ Chile

As it can be seen in Table 3, the efficient Brazilian companies are from the sectors of Foods and Beverages, Commerce, Construction, Paper and Cellulose, Oil 
and Gas, Chemical, and Steel and Metallurgical. It is exclusively responsible for cases of efficiency in the sectors of Commerce, Construction, Chemicals and Steel and Metallurgical. Chemical sector is responsible for 5.5\% of its exports and Steel and Metallurgical for 7.5\% (OEC 2016a). On the other hand, the most efficient Chilean companies are from Agriculture and Fishing, Foods and Beverages, Mining, Non-metallic Minerals, and Paper and Cellulose sectors. Chile is totally responsible for the cases of efficiency in the sectors of Agriculture and Fishing, Mining and Non-Metallic. Agriculture and Fishing corresponds to $19.5 \%$ of the total exports, and Mining and Non-metallic Minerals correspond to 53.76\% (OEC 2016b). A fast analysis leads to the conclusion that Chile is more focused on being efficient in sectors important for its exports.

The list of efficient DMUs under the VRS assumption is shown in Table 4 (Appendix A). It is possible to observe for the VRS assumption that the results had less discriminant power with more than $1 / 3$ of the DMUs tied as efficient.

\subsection{Industry analysis}

\subsubsection{Sectors where both countries present efficient firms}

\section{Food and beverage}

The efficient Chilean companies Concha y Toro (Concha y Toro 2017) and Emiliana are both vineyards focused on the international market. According to official sources, Concha y Toro exported products with a total value of more than U\$320 million in 2012, and Emiliana, U\$29 million for the same period (Commercial Department of Chile 2017). Only 422 Brazilian firms exported a total value superior to U\$100 million in 2012 and 351 in 2016 (Ministry of Industry, Exterior Commerce and Services 2016).

Emiliana has been characterized also for being focused on organic wines and it is currently the largest organic vineyard in the world, exporting to no less than 60 counties (Concha y Toro 2017; Emiliana 2017).

Concha y Toro's penetration to international markets started in the early 2000 s, with the astronomic rise in the following years. Mora (2009) points out growth of 257\% in volume sales between 2000 and 2004 (about three times the growth of the 
other Chilean producers) and 226\% in revenues (five times the growth of the other Chilean producers). Between 2000 and 2013 it has gained a global scale presence and it is currently is the seventh largest wine producer in the world.

Contrary to the Chilean cases, Brazilian companies in this sector are focused on the national and local market. Josapar is a distributor of grains (Josapar 2017) and it is among the 1000 largest exporters in Brazil, between US\$10 and US\$50 million in 2016 (Ministry of Industry, Exterior Commerce and Services 2016). Minupar is a holding focused on dealing food (mainly chicken) in the national and local market through importation and exportation. It is not mentioned in the official reports as one of the biggest Brazilian operators. Tereos is an international group that operates in Brazil. Its activities in Brazil are related to sugarcane plantation for sugar (focused on the inner and exterior market) and ethanol (inner market) production (Tereos 2017). It is among the 5000 largest exporters of Brazil, between US $\$ 1$ and US\$5 million in 2016 (Ministry of Industry, Exterior Commerce and Services 2016).

AMBEV dominates the Brazilian beverage market and it is one of the largest companies in the sector in the world, but it is the last in the efficiency rank among the analyzed companies from Foods and Beverage sector, using this DEA approach. In 2004, AMBEV merged with Interbrew, creating InBev, which became the largest in the world (Financial Times 2017). According to Economática software, in 2012, AMBEV alone was the largest company in Latin America. One of the reasons for its ranking may be the variable return to scale. AMBEV is among the 1000 largest exporters in Brazil, between US\$10 and US\$50 million in 2016 (Ministry of Industry, Exterior Commerce and Services 2016).

JBS is a Brazilian food company, focused processing and trading animal protein to the inner and the exterior market. It is also involved in the production, cogeneration, and commercialization of electric power, provision of cattle fatting and transportation services. JBS also manages industrial residue, produces and commercializes steel cans, plastic resins, soap base, soap bar, biodiesel, glycerin, fatty acid, collagen, and wrapper, as well as wet blue, semi-finished, and finished leather products; and it purchases and sells soybean. In addition, it engages in trading cooked frozen meat; logistics and warehousing operations; and distribution center and harbor, waste, among other business (JBS Fiboi 2017). JBS is classified 
in Food and Beverage sector according to Economática and it is among the companies which exported more than U\$100 million in 2012 and in 2016 (Ministry of Industry, Exterior Commerce and Services 2016), but it is considered inefficient through DEA approach. One of the reasons for its ranking is a variable return to scale.

Feria de Osorno is a Chilean company in the production, distribution, import, export, and sale of food products to farmers in Chile. Feria de Osorno operates through two segments, Agricultural and Investment. It primarily offers consumable and industrial meat products, and food sub products, as well as dairy products (Feria de Osorno 2017). Although this segment may be directly comparable to JBS core operations (meat supply), Feria de Osorno is classified in Agriculture and Fishing sector by Economática. The company also offers agricultural technology and supplies, rent-a-car services, technological machinery and equipment, vehicles, fuels, financial and administrative services, cattle trade brokering services, fertilization and veterinary supplies and services, agrochemicals, safety items, and cattle slaughter services, among other business (Feria de Osorno 2017). The company was responsible for more than U\$95 million in exports in 2012 (Commercial Department of Chile 2017) As well as JBS, Feria de Osorno is also considered inefficient in its sector (Agriculture and Fishing), probably due to the scale inefficiency. A direct comparison between both companies was not possible due to the limitations of classification of the databank.

\section{Paper and cellulose}

The efficient Chilean company Celulosa Arauco y Constitución S.A (Arauco) is part of the COPEC holding and it produces the wood pulp, engineered wood, and forestry. It has positioned as one of Latin America's largest forest owners with the total land holding of around 1.5 billion hectares with 4 plants in Chile, 2 in Argentina, and 2 in Brazil (Arauco 2017). Arauco was responsible for more than U\$1.7 billion of Chilean exports in 2012. The other segments of the Arauco group were jointly responsible for more than $\mathrm{U} \$ 800$ million in the same year (Commercial Department of Chile 2017). Currently, Arauco has customers in 75 countries 
covering different segments from producers of household wood fiber-based products to businesses creating furniture, and construction and industrial.

Celulose Irani and Santher are minor companies in the Brazilian cellulose market share. Irani produces paper and wood resins (Irani 2017). Santher is a diversified holding, but Santa Teresinha refers specifically to the operations of paper production (Santher 2017). Santher and CMPC are among the 1000 largest exporters of Brazil, between US $\$ 10$ and US $\$ 50$ million in 2016 (Ministry of Industry, Exterior Commerce and Services 2016).

The three biggest Brazilian companies responsible for cellulose (and derivate) exportations, Kablin, Suzano, and Fibria (each one responsible for more than U\$100 million in exports) were considered inefficient (Ministry of Industry, Exterior Commerce and Services 2016; Exame 2017).

CMPC made its largest investment between 2009 and 2015 with the start of the second line of Guaíba, Brazil (CMPC 2017). It is the last in the rank among the analyzed companies from Paper and Cellulose sector using this DEA approach, but being efficient until 2015 and inefficient in the overall system. This period coincides with its largest investment.

\section{Oil and gas}

Gasco is a distributor of gas for domestic (through ducts) and industrial (through cylinders and ducts) consumption in 13 of the 17 Chilean States (Gasco 2017). The gas supply through ducts for domestic consumption is common in the most populated regions of Chile.

CEG RIO explores the distribution of natural gas (through ducts) and its byproducts in the State of Rio de Janeiro (one of the 27 Brazilian States) (CEG Rio 2017). In Brazil, it is common to supply gas for domestic consumption in cylinders (even for the most populated areas). The gas supply through ducts advantages the efficiency of the inventory control system because there is no need of physical storage of the gas cylinders. That suggests that both companies were benefited by their operational characteristics.

COPEC is a Chilean holding that commercializes fuels, but due to investments in sectors such as forestry, liquefied gas, natural gas, and fishing, responsible for 
U\$99 million of Chilean exports in 2012 (Commercial Department of Chile 2017). COPEC also controls cellulose Arauco (COPEC 2017). Although Arauco is the most efficient company in its sector, COPEC is the last in the rank among the analyzed companies from Oil and Gas sector using this DEA approach. One of the reasons for its ranking is a variable return to scale.

Petrobras is responsible for a large part of Brazilian exports (it is among the 3 biggest exporters together with Vale and Embraer) (Ministry of Industry, Exterior Commerce and Services 2016; Petrobras 2017). It is the last in the rank among the analyzed companies from the Oil and Gas sector using this DEA approach, being efficient until the third quarter of 2015, but inefficient in the overall system. The first inefficient period coincides with its announcement of the company's worst loss. Another reason for its ranking is because of a variable return to scale.

\subsubsection{Sectors where only Chile presents efficient firms}

\section{Agriculture and fishing}

Viconto is a Chilean company that plants fruits and nuts for exportation, among the challenges of its operations is to stock and transport the fruits in low temperatures raises, markets, and exports fresh and frozen fruits and vegetables. It owns plantations in Central Chile and grows apples, pears, peaches, nectarines, plums, apricots, cherries, raspberries, blueberries, kiwis, asparagus, avocados, and lemons (Viconto 2017) In 2012, eleven companies specialized in trading fruits exports jointly more than U\$11 million (Commercial Department of Chile 2017), Viconto may export through one of these dealers. They operate 447.45 ha in four different valleys in Chile. As of 2015, they have a market of 65,366 tons with major destinations in the United States of America, Canada and Europe (Viconto 2016).

Schwager is classified in the software as agriculture and fishing, but it is actually mining and energy (Schwager 2017). The misclassification of this databank is one of the limitations of the present paper.

Sofruco is a company of products related to nuts, juice, fresh fruit, plums and honey. In terms of prices, the company has been facing a dispersed scenario, with moderate declines, mainly in wines, and has been maintaining a strategy for 
optimizing production costs since 2011 (Sofruco 2017). Sofruco exported more than U\$ 11 million in 2012 (Commercial Department of Chile 2017). It is the last in the rank among the analyzed companies from Agriculture and Fishing sector using this DEA approach. The inefficient periods coincide with the adoption of its cost strategy.

\section{Mining}

Considering the number of studied Chilean companies, $10.17 \%$ were from the sectors of mining or non-metallic minerals, and all of them were efficient.

Pucobre is a Chilean miner engaged in copper mining in the northern Atacama region. In 2011 it has increased its stake in the El Espino copper-gold project to $100 \%$ (Pucobre 2017). It is important to emphasize that copper (refined copper and copper ore) is responsible for $44 \%$ of Chilean exports. Soprocal is a Chilean company that acquires ore deposits and produces calcium, carbonates, and lime, selling it within mining industries (Soprocal 2017). SQM is a Chilean company focused on exports and it is the world's biggest producer of lithium. Its natural resources are extracted from the Atacama region (SQM 2017). In 2012, Pucobre and SQM exported, respectively, U\$47 and U\$430 million (Commercial Department of Chile 2017).

Vale is one of the largest mining companies in the world and is also the largest producer of iron ore, pellets, and nickel. It is also the largest Brazilian exporter (more than US\$ 10 billion, representing 5.9\% of Brazilian exports). The company suffered in 2015 with the adversities of the mining sector, the fall in iron ore prices, and the devaluation of the real (Vale 2017). It is the last in the rank among the analyzed companies from Mining sector using this DEA approach. The inefficient period coincides with its adversities suffered. Another reason for its ranking is because of a variable return to scale.

\section{Non-metallic minerals}

Cementos Bío-Bío is a Chilean company, founded in 1957, that produces cement, lime, and pre-mixed concrete and provides services to the cement industry (Bío Bío 2017) and exported U\$12 million in 2012 (Commercial Department of 
Chile 2017). Cemento Polpaico is a Chilean Company, founded in 2001, that also produces cement and offers aggregates, including sand and gravel. Polpaico is controlled by the builder group Lafarge Holcim. Although it is an opened capital enterprise, there is no data about this company in Economática, because it is negotiated in Euronext (Polpaico 2017). This kind of solution (a builder that incorporates de cement supplier) is inexistent among the biggest Brazilian builders. Companies that manage the whole supply chain apparently tend to be more efficient. Cristalerias de Chile produces glass and plastic containers in Chile and it sells its products to pharmaceutical, food, wine, liquor, beer, and nonalcoholic beverages manufacturers (CristalChile 2017). It exported U\$0.9 million in 2012 (Commercial Department of Chile 2017).

The inefficient Nadir Figueiredo is a Brazilian glass producer among the 1000 largest exporters in Brazil, between US\$10 and US\$50 million in 2016 (Ministry of Industry, Exterior Commerce and Services 2016). The company suffered from the industrial crisis in Brazil since 2015 (Nadir 2017). It is the last in the rank among the analyzed companies from non-metallic minerals sector using this DEA approach. The inefficient period coincides with the industrial crisis.

\subsubsection{Sectors where only Brazil presents efficient firms}

\section{Steel and metallurgical}

Paranapanema is a company that produces refined copper and also offers semifinished products of copper and copper alloy (Paranapanema 2017). It is among the 40 largest exporters in Brazil, above US\$100 million in 2016 (Ministry of Industry. Exterior Commerce and Services 2016). Already efficient mentioned Chilean company in the mining sector (Pucobre) is one of the suppliers of Paranapanema, which is also efficient in manufacturing products with copper. The relationship among efficient companies in the same supply chain merits further study.

Ferbasa is a metallurgical company that manufactures products of iron metals and also explores iron deposits (Ferbasa 2017). It is among the 300 largest exporters in Brazil, above US\$100 million in 2016 (Ministry of Industry, Exterior Commerce and Services 2016). Iguaçu is a metallographic company that manufactures 
packaging products. It is specialized in metal cans and focused on the inner market (Iguaçu 2017).

One of the limitations of the analysis of this sector is that one of the ten greatest producers of refined copper in the world, the Chilean company Antofagasta Minerals, is not on Economática databank. It is the biggest traded company in Chile, but its stocks are only negotiated in London Stock Exchange (LSE) (Antofagasta 2017). Antofagasta Minerals exported U\$ 2 million in 2012 (Commercial Department of Chile 2017). The world biggest producer of refined copper, the Chilean company CODELCO, is a state company so its data are also out of Economática databank (Codelco 2017). In the last 12 years, CODELCO has exported approximately $18 \%$ of Chile's total exports (Codelco 2015; Commercial Department of Chile 2017).

Elecmetal is a Chilean steel company (Elecmetal 2017) and a representative Chilean exporter which main importers are the US, Peru, and Brazil responsible for U\$ 9 million of exports (Commercial Department of Chile 2017). Elecmetal is inefficient according to the present DEA approach but owns major shares of Cristalerias, which is a benchmark of efficiency in the sector of non-metallic minerals.

Although we observed case where several companies of the same supply chain (even from different sectors and countries) were efficient, e.g., Pucobre (Chilean) and Paranapanema (Brazilian), there was no case of simultaneously efficiency between a controlled company and the controller holding. e.g., Arauco (efficient)COPEC (inefficient), Cristalerías (efficient)-Elecmetal (inefficient). This topic deserves further study.

\section{Chemicals}

Ultra-Ultrapar is a holding focused on the distribution of fuels and chemicals, it is mainly focused on the inner market (Ultra 2017). Cristal Pigmentos produces chemical products (BMFBOVESPA 2017a). It is among the 4000 largest exporters in Brazil, between US $\$ 1$ and US $\$ 5$ million in 2016 (Ministry of Industry, Exterior Commerce and Services, 2016). Fer Heringer produces and distributes agricultural fertilizers (BMFBOVESPA, 2017b). It is among the 2500 largest exporters in Brazil, 
between US\$5 and US\$10 million in 2016 (Ministry of Industry, Exterior Commerce and Services, 2016).

Edelpa is a Chilean company that manufactures packages and packs liquid alimentary products (such as soup, drinks, etc.), and it is considered inefficient through DEA results. It is focused on the inner market (Edelpa 2017). An obvious reason why this company is strongly less efficient than its pairs (other packing firms) was not found. A case study should be conducted for understanding this outlier.

\section{Commerce}

Battistella is a Brazilian company whose main activity is wholesale industrial supplies and equipment (Battistella 2017). It is part of a conglomerate that operates in other sectors and it is among the 2000 largest exporters of Brazil, between US $\$ 10$ and US\$50 million in 2016 (Ministry of Industry, Exterior Commerce and Services 2016).

BR Pharma is a Brazilian company focused on the inner market. The company operates a network of retail pharmacies located in Midwest, Northeast and Southern regions of Brazil. The Brazilian drugstore market changed and increased drastically from 2008 until 2012, due to the aging of the population and the economic boom. It is a highly competitive and pulverized (BR Pharma 2017). Even the holding UltraUltrapar entered in this market in the period, but it is considered inefficient in this DEA approach. This is a case which the controller is efficient but the controlled isn't. BR Pharma (as well as Ultra) is one of the ten biggest players of this market (which jointly attend 36\%), it is the result of several fusions and acquisitions from 2010 until 2012. The efficient result is not expected because BR Pharma is was the only firms (among its pairs) with constant negative results since its creation until 2015. For a complete overview of the Brazilian retail drugstore market, an interested reader may consult (Fernandes et al. 2016). BR Pharma may be the focus of further investigations.

One of the limitations of the analysis of this sector is that the biggest Chilean networks of retail drugstores are not on Economática databank, because they do not have public data. Farmacias Ahumada had stocks in Bolsa de Santiago, but it 
canceled its participation in the second quarter of 2015 (Santiago Stock Exchange 2015). The others Chilean networks of retail drugstores (e.g. Cruz Verde and Salcobrand) are held companies.

Forus is a Chilean company that manufactures footwear products (Forus 2017). It is the last in the rank among the analyzed companies from Commerce sector using this DEA approach, so it is inefficient but only efficient during the first period of the first year. One of the reasons could be seasonality, because usually, footwear products have sales peaks at a specific date, such as near mother's day and near new year's eve. It was possible to notice a more pronounced decrease in efficiency in the last quarter of the year, suggesting uncontrolled inventory levels to meet demand during the fourth quarter of the new year's eve. Before these seasons dates, the inventories level are high, and after these dates, the inventories are low (compared to before). So companies that have seasonal sales tend to be less efficient than the ones that sell many kinds of products the whole year.

According to Brazilian Institute of Retail Executives and Consumer Market (IBEVAR 2017), Lojas Americana is the largest Brazilian retail company for electronics and furniture business, followed by Magazine Luiza that it is also one of the ten largest Brazilian retail companies considering all products, as well as Cencosud, a Chilean company with operations in Brazil (IBEVAR 2017). Although both are inefficient, Magazine Luiza achieved greater efficiency in certain periods. This coincides with record earnings before the beginning of Brazilian economic crisis (from 2015 on), while the inefficient period of Lojas Americanas coincides with the losses of its controller holding, B2W (mainly from June 2014 on, i.e., one year before the critical fall of consumption due to the national crisis). The losses of B2W may be a consequence of inner alterations of management, an interested reader may consult (Correa 2013). Another observation that can be made is that during 2015 (the peak of crisis) Magazine Luiza grew more than the Chilean competitor Cencosud, which also operates in Brazil, surpassing it in that year (IBEVAR 2017). Although 2011 and 2012 have been years of profits followed by small losses for Magazine Luiza, 2013 and 2014 were years of record profits for the company. In the year 2015 , the company suffered a loss of $\mathrm{R} \$ 52.4$ million (7.82 times greater than 
the loss in 2012). Physical stores started to grow again only in the third quarter of 2016.

\section{Construction}

Among the efficient cases, Azevedo \& Travassos is an engineering and construction company that operates heavy constructions, such as airports, highways, bridges, tunnels, and other civil engineering projects (Azevedo 2017); Lix da Cunha is also an engineering company that constructs highways, commercial buildings, and residential housing complexes (Lix da Cunha 2017); and PDG Realty is a real state investment company that operates in residential development, allotments, and it also aims for commercial rental income (PDG 2017)

Among the Chilean inefficient cases, Salfacorp is the biggest Chilean company in the sector, it is focused on the development and management of engineering, construction, and assembly projects, and invests in commercial real estate and financial securities (Salfacorp 2017). This case of inefficiency is possible due to variable return to scale since it is the biggest company in the sector. Besalco provides construction services, it builds highways, bridges, buildings, tunnels, sanitation systems, industrial piping, and underground systems (Besalco 2017). Socovesa is a real estate firm which provides construction, project management, development, engineering, design and sales services (Socovesa 2017). Comparative case studies among Azevedo \& Travassos, Lix da Cunha and Belsaco, and between PDG Realty and Socovesa are recommended.

MRV is a Brazilian company that plans and constructs residential buildings in six states from Brazil. It was considered inefficient. It is recommended to perform a case study. It was not found a Brazilian company which integrates other segments of the supply chain in the same holding, as the Chilean builder group Lafarge Holcim that controls Cementos Polpaico, a firm that produces cement and offers aggregates, including sand and gravel. This case requires further studies, beyond the scope of the present paper. 


\section{Concluding remarks}

This paper presented an application of DDEA-OCT for comparing inventory controls system of companies from different sectors in Brazil and Chile in terms of cost efficiency. This model aims to obtain more realistic results considering specific characteristics of inventory control systems, incorporating the relationship among demand, production, and inventory through OCT in DDEA models, and facilitating the comparison among companies of these developing countries.

Although both countries are emerging economies, Chile has been one of the fastest growing economies in Latin America in the last decade, while Brazil has not. This paper aimed to measure the efficiencies of the inventory control systems of the companies, assuming that it is critical for companies' success which, in turn, impacts on countries' development. The results of this paper showed that Chilean efficient companies were, mainly, the exporter ones, while the Brazilian efficient cases were, mainly, companies focused on the inner market. Chile's development may be explained due to the fact that exporter Chilean companies are more pressured to be efficiently managed in a globally competitive environment. These DMUs can be used as benchmarks for the Brazilian ones.

The model was applied to the inventory control system of 141 companies (82 from Brazil and 59 from Chile), between the fourth quarter of 2010 until the first quarter of 2016, using accounting data from Economática databank.

The DDEA-OCT application under CRS assumption has identified 29 efficient companies among the 10 sectors. These efficient companies were mainly exporters in both countries. Though in Chile, the efficient companies are responsible for a high percentage of national exports (such as mining, non-metallic minerals, and agriculture \& fishing), while, the Brazilian efficient companies were those of sectors that do not correspond to a high percentage of exports (such as commerce, construction, chemical, and steelworks \& metallurgical). For the VRS assumption, the results had less discriminant power with more than $1 / 3$ of the DMUs tied as efficient. For further studies, the suggestion is to explore tiebreaking methods in dynamic cost efficiency problems under VRS assumption. 
The discussions of the results investigated patterns and intrinsic reasons that may be influenced by the differences in each country's, e.g., the relationship between efficient and non-efficient companies that belong to the same supply chain or a company and its controller holding. This amplitude of investigation was possible because the study incorporated several distinct sectors in the same analysis.

Among the least efficient (last in the rankings of each sector), some patterns can be observed. One of the major causes for the companies that were inefficient in all the periods is a possible variable return to scale since they usually were the greatest companies in each sector.

Another observed pattern is for inefficient companies, that were efficient for a certain period (usually until 2015), and they were only inefficient in the last few periods, so one of the major causes is an "event", such as an economic crisis. The difference between an efficient company and a company that was inefficient only during the economic crisis is not because the efficient ones do not suffer from the crisis, but they take better strategies and decisions in these periods. Another reason for the large companies is a natural difficulty to change and adapt their strategies over the crisis due to their inertia.

Another pattern is that companies from holdings and conglomerates that operate in supply chains tend to appear among the efficient DMUs. One of the reasons is because when a group manages an entire supply chain, it can avoid the bullwhip effect, being more effectively controlling and managing inventories.

There are other observations that can be made about the classification of DMUs in each sector. For example, following the classification of Economática, the Nonmetallic Minerals industry has heterogeneous companies and it may not reflect the reality of the sector. Some companies have a different classification, e.g. Schwager is a mining and energy company classified as agriculture and fishing.

The limitations of this paper are related to data availability. It was not possible to find data from some important companies for some sectors, such as Antofagasta Minerals and CODELCO. Six sectors (finance and insurance, software, and data, fund, as well as the sectors related to the provision of services, such as electric energy, transport, telecommunications, and the category others) and DMUs with zeros, negative or missing data were excluded. And after that, four sectors 
(Electronics, Industrial Machines, Textile, and Vehicles and Parts) had only data from one country, so it was not possible to use them to compare both countries.

This study provides insights about the performance of the inventory management of companies from Brazil and Chile, and it can be used for benchmarking purpose by other researchers. The focus of this study was on the impact of companies' inventory management to developing countries, though other factors not included in the model could affect the development. So for future study, it is suggested including variables and analysis of the social and environmental impacts.

\section{Acknowledgement}

We thank the Coordination for the Improvement of Higher Education Personnel (CAPES) for their financial support.

\section{References}

Alves Junior P.N., Cari E.P.T. (2017), The use of optimal control theory as a benchmarking tool in production-inventory systems, in: Handbook of research on applied optimization methodologies in manufacturing systems, Yılmaz Ö.F., Tüfekçí S. (eds), IGI Global, Hershey, PA, pp. 284-308.

Banker R.D., Charnes A., Cooper W.W. (1984), Some models for estimating technical and scale inefficiencies in Data Envelopment Analysis, „Management Science”, vol. 30 no. 9, pp. 1078-1092.

Charnes A., Cooper W.W. (1962), Programming with linear fractional functionals, „Naval Research Logistics Quarterly”, vol. 9 no. 3-4, pp. 181-186.

Charnes, A., Cooper W.W., Rhodes E. (1978), Measuring the efficiency of decision making units, „European Journal of Operational Research”, vol. 2 no. 6, pp. 429-444.

Chilan C.M., Conway B.A. (2015), A reachable set analysis method for generating nearoptimal trajectories of constrained multiphase systems, „Journal of Optimization Theory and Applications", vol. 167 no. 1, pp. 161-194.

Cooper W.W., Seiford L.M., Tone K. (2007), Data Envelopment Analysis. A comprehensive text with models, applications, references and DEA-solver software, Springer, New York.

Correa C. (2013), Sonho Grande, Sextante/Gmt, São Paulo. 


\section{INSIDER UNDERSTANDING OF COUNTRY DEVELOPMENT ...}

Debreu G. (1951), The coefficient of resource utilization, „Econometrica”, vol. 19, pp. 273292.

Doupnik T.S., Hoyle J.B., Schaefer T.F. (2013), Advanced accounting, 11th edition, McGraw-Hill, New York.

Duan Y., Cao Y., Huo J. (2018), Optimal pricing, production, and inventory for deteriorating items under demand uncertainty. The finite horizon case, „Applied Mathematical Modelling", no. 58, pp. 331-348.

Fallah-Fini S., Triantis K., Johnson A.L. (2014), Reviewing the literature on non-parametric dynamic efficiency measurement. State-of-the-art, „Journal of Productivity Analysis”, vol. 41 no. 1, pp. 51-67.

Farrell M.J. (1957), The measurement of productive efficiency, „Journal of the Royal Statistical Society", vol. 120, pp. 253-290.

Feichtinger G., Hartl R. (1985), Optimal pricing and production in an inventory model, „European Journal of Operations Research”, vol. 19 no. 1, pp. 45-56.

Fernandes I.R.C., Melo I.C., Alves Junior P.N., Rbelatto D.A.N. (2016), Brazilian drugstores market. An overview of the main characteristics and players, in: Annals of XXIV SIMPEP (Symposium of Production Engineering), UNESP - State University of São Paulo, Bauru, pp. 2-14.

Fico C. (2008), Ditadura e democracia na América Latina. Balanço histórico e perspectivas, FGV Editora, Rio de Janeiro.

Gonzalez M., Espín J.J.L., Aparicio J., Giménez D., Pastor J.T. (2015), Using genetic algorithms for maximizing technical efficiency in Data Envelopment Analysis, „Procedia Computer Science”, vol. 51 no. 1, pp. 374-383.

Hatefi S.M., Jolai F., Iranmanesh S.H., Kor H. (2009), A new DEA model for classification intermediate measures and evaluating supply chain and its members', in: 2009 International Conference on Computer Engineering and Technology, IEEE, Singapore, pp. 457-461.

Hochman G., Rajagopal D., Timilsina G., Zilberman D. (2011), The role of inventory adjustments in quantifying factors causing food price inflation, Policy Research Working Paper no. WPS 5744, http://documents.worldbank.org/curated/en/860221468326686333/The-role-of-inventoryadjustments-in-quantifying-factors-causing-food-price-inflation [01.02.2019].

Holt C.C., Modigliani F., Muth J.F., Simon H.A. (1960), Planning production, Inventories, and work force, Prentice-Hall, New Jersey. 
Lira Neto J.C. (2013), Getúlio, Companhia das Letras, São Paulo.

Ministry of Industry, Exterior Commerce and Services (2016), Brazilian companies: importers and exporters, http://www.mdic.gov.br/comercio-exterior/estatisticas-de-comercioexterior/empresas-brasileiras-exportadoras-e-importadoras [09.09.2017].

Mora P. (2009), Is branding an efficient tool for the wine industry? Three case studies, „International Journal of Case Method Research \& Application”, vol. 21 no. 2, pp. 128-138.

Sengupta J.K. (1999), A dynamic efficiency model using data envelopment analysis, „International Journal of Production Economics”, vol. 62 no. 3, pp. 209-218.

Sethi S.P., Thompson G.L. (2006), Optimal control theory. Applications to management science and economics, Springer, New York.

Stevenson W.J. (2012), Operations management. Theory and practice, McGraw-Hill/Irwin, New York.

Thompson G.L., Sethi S.P. (1980), Turnpike horizons for production planning, „Management Science”, vol. 26 no. 3, pp. 229-241.

Tone K. (2001), A slacks-based measure of efficiency in data envelopment analysis, „European Journal of Operational Research”, vol. 130 no. 3, pp. 498-509.

Tone K., Tsutsui M. (2014), Dynamic DEA with network structure. A slacks-based measure approach, „Omega”, vol. 42 no. 1, pp. 124-131.

Zhao Y., Zhao C., He M., Yang C. (2016). A state-feedback approach to inventory control. Analytical and empirical studies, „Production and Operations Management”, vol. 25, no. 3, pp. 535-547.

Zhu J. (2009), Quantitative models for performance evaluation and benchmarking. Data Envelopment Analysis with spreadsheets, Springer, New York.

Zhu J. (2014), Quantitative models for performance evaluation and benchmarking, Springer International Publishing, Cham.

\section{Internet resources}

Antofagasta (2017), Antofagasta PLC, http://www.antofagasta.co.uk/ [20.09.2017].

Arauco (2017). Celulosa Arauco y Constitucion S.A. - Sustainable Forest Product Manufacturer, http://www.arauco.cl/ [20.09.2017].

Azevedo (2017), Azevedo \& Travassos S.A., http://azevedotravassos.com.br/portal/ [26.09.2017]. 


\section{INSIDER UNDERSTANDING OF COUNTRY DEVELOPMENT ...}

Besalco (2017), Besalco S.A., http://www.besalco.cl/ [26.09.2017].

Bío Bío (2017), Cementos Bío Bío S.A., https://cementosbiobio.cl/ [20.09.2017].

BMFBOVESPA (2017a), Cristal pigmentos do Brasil S.A., http://bvmf.bmfbovespa.com.br/cias-listadas/empresas-

listadas/ResumoEmpresaPrincipal.aspx?codigoCvm=11398\&idioma=pt-br [20.09.2017].

BMFBOVESPA (2017b) Fertilizantes Heringer S.A., http://bvmf.bmfbovespa.com.br/ciaslistadas/empresas-listadas/ResumoEmpresaPrincipal.aspx?codigoCvm=20621\&idioma=pt-br [20.09.2017].

BR Pharma (2017), BR Pharma, http://ri.brasilpharma.com.br/ [21.09.2017].

CEG Rio (2017), Ceg Rio S.A. - Gas Natural Fenosa Brasil. https://www.gasnaturalfenosa.com.br/br/servicos+de+gas+rio+de+janeiro/para+a+sua+casa/ distribuicao+de+gas+natural/tarifas/1297313692091/ceg+rio+.html [20.09.2017].

CMPC (2017), Empresas CMPC S.A. - Celulose Riograndense, http://www.celuloseriograndense.com.br/empresa/cmpc [20.09.2017].

Codelco (2015), Codelco - $\quad$ Memorial Annual, https://www.codelco.com/memoria2015/pdf/memoria-anual/memoria-anual-codelco2015.pdf [20.09.2017].

Codelco (2017), Codelco - Corporación Nacional del Cobre, Chile, https://www.codelco.com/ [20.09.2017].

Commercial Department of Chile (2017), ProChile - Importadores - Directorio Exportador, http://www.prochile.gob.cl/importadores/directorio-exportador/?re=1 [20.09.2017].

Concha y Toro (2017), Vina Concha y Toro S.A., https://www.conchaytoro.com/?lang=es_es [19.09.2017].

Copec (2017), Empresas Copec S.A. - History, http://www.empresascopec.cl/en/empresascopec/historia/ [20.09.2017].

CristalChile (2017), Cristalerias de Chile S.A., http://www.cristalchile.cl/ [20.09.2017].

Edelpa (2017), Edelpa - Envases del Pacífico S.A., http://www.edelpa.cl/ [20.09.2017].

Elecmetal (2017), Elecmetal - Compañía Electro Metalúrgica S.A., http://www.meelecmetal.com/es/ [20.09.2017].

Emiliana (2017), Viñedos Emiliana S.A. - Organic Vineyards, http://www.emiliana.cl/ [19.09.2017]. 
Exame (2017), Revista Exame - Ranking do sertor de papel e celulose em 2016 (Ranking of the pulp and paper sector in 2016), mm.exame.abril.com.br/empresas/filtrar/2016/papel-ecelulose/Todos [20.09.2017].

Ferbasa (2017), Ferbasa - Cia de Ferro Ligas da Bahia S.A., http://www.ferbasa.com.br/default_pti.asp?idioma=0\&conta=45 [20.09.2017].

Feria de Osorno (2017), Feria de Osorno S.A., http://www.fossa.cl/inicio.html [21.09.2017].

Financial Times (2017), The lean and mean approach of 3G Capital, https://www.ft.com/content/268f73e6-31a3-11e7-9555-23ef563ecf9a [19.09.2017].

Forus (2017), Forus S.A., http://forus.cl/en [28.09.2017].

Gasco (2017), Empresas Gasco S.A., http://www.gasco.cl/ [20.09.2017].

IBEVAR (2017), IBEVAR - Brazilian Institute of Retail and Consumer Executives, http://www.ibevar.org.br/ [27.09.2017].

Iguaçu (2017), Metalgráfica Iguaçu S.A., http://www.metaliguacu.com.br/index.php [20.09.2017].

Irani (2017), Celulose Irani S.A., http://www.irani.com.br/ [20.09.2017].

JBS Friboi (2017), Friboi-JBS S.A., https://www.friboi.com.br/a-empresa [21.09.2017].

Josapar (2017), Josapar - Joaquim Oliveira Participações S.A., http://josapar.com.br/ [19.09.2017].

Lix da Cunha (2017), Construtora Lix da Cunha S.A., http://www.lix.com.br/ [26.09.2017].

Nadir (2017), Nadir - Nadir Figueiredo Indústria e Comércio S.A., http://www.nadir.com.br/ [20.09.2017].

OEC (2016a), The Observatory of Economic Complexity - Brazil, http://atlas.media.mit.edu/en/profile/country/bra/\#Exports [09.09.2017].

OEC (2016b), The Observatory of Economic Complexity - Chile, http://atlas.media.mit.edu/en/profile/country/chl/ [09.09.2017].

OECD (2017a), OECD Economic Outlook - Brazil. Preliminar, https://www.oecd.org/eco/outlook/economic-forecast-summary-brazil-oecd-economicoutlook-june-2017.pdf [20.09.2017]. 
OECD (2017b), OECD Economic Outlook - Chile - Preliminar, http://www.oecd.org/eco/outlook/economic-forecast-summary-chile-oecd-economicoutlook-june-2017.pdf [20.09.2017].

Paranapanema (2017), Paranapanema S.A., http://www.caraiba.com.br/ [20.09.2017].

PDG (2017), PDG S.A., ri.pdg.com.br [26.09.2017].

Petrobras (2017), Petrobras - Petróleo Brasileiro S.A., http://www.petrobras.com.br/pt/ [20.09.2017].

Polpaico (2017), Cemento Polpaico S.A. - LafargeHolcim, http://www.holcim.cl/parking [20.09.2017].

Portales L.F. (2015), Los mitos de la democracia chilena, http://www.catalonia.cl/los-mitosde-la-democracia-chilena-vol-ii-desde-1925-1938-p-2665.html [26.09.2017].

Pucobre (2017), Pucobre - Sociedad Punta del Cobre S.A., http://www.pucobre.cl/ [20.09.2017].

Salfacorp (2017), SalfaCorp S.A., http://www.salfacorp.com/ [26.09.2017].

Santher (2017), Santher - Fábrica de Papel Santa Therezinha S.A., http://www.santher.com.br/ [20.09.2017].

Santiago Stock Exchange (2015), Comunicacion Interna $\mathrm{N}^{\circ}$ 12.721, http://www.bolsadesantiago.com/noticias/SiteAssets/Lists/Noticias BCS/EditForm/CI 12721 Cancela inscripción a FASA.pdf [20.09.2017].

Sarimveis H., Patrinos P., Tarantilis C.D., Kiranoudis C.T. (2008), Dynamic modeling and control of supply chain systems. A review, „Computers \& Operations Research”, vol. 35, pp. 3530-3561.

Schwager (2017), Schwager S.A., http://www.schwager.cl/web/ [20.09.2017].

Socovesa (2017), Empresas Socovesa S.A., http://www.empresassocovesa.cl/ [26.09.2017].

Sofruco (2017), Sociedad Agrícola La Rosa Sofruco S.A., http://www.sofruco.com/en/ [20.09.2017].

Soprocal (2017), Soprocal S.A., http://www.soprocal.cl/soprocal/ [20.09.2017].

SQM (2017), SQM - Sociedad Química y Minera S.A., http://www.sqm.com/ [20.09.2017].

Tereos (2017), Tereos S.A., https://tereos.com/pt [19.09.2017]. 
Ultra (2017), Ultrapar - Ultra Participações S.A., http://www.ultra.com.br/ [20.09.2017].

Vale (2017), Vale S.A., http://www.vale.com/brasil/PT/Paginas/default.aspx [20.09.2017].

Viconto (2016), Frutícola Viconto S.A. - Memória 2015, http://www.viconto.cl/wp/wpcontent/uploads/2016/04/Memoria-2015-Final-SVS.pdf [20.09.2017].

Viconto (2017), Frutícola Viconto S.A., http://www.viconto.cl/ [20.09.2017].

World Bank (2016a), Brazil overview, http://www.worldbank.org/en/country/brazil/overview [09.09.2017].

World Bank (2016b), Chile overview, http://www.worldbank.org/en/country/chile/overview [09.09.2017]. 


\section{Appendix A}

Table 4. Efficient DMUs considering the CRS and VRS assumptions

\begin{tabular}{|c|c|c|c|c|c|}
\hline Sector & Country & DMU & $\begin{array}{l}\text { Efficiency } \\
\text { (CRS) }\end{array}$ & $\begin{array}{l}\text { Efficiency } \\
\text { (VRS) }\end{array}$ & $\begin{array}{l}\text { Returns to } \\
\text { Scale }\end{array}$ \\
\hline \multirow[t]{9}{*}{$\begin{array}{l}\text { Agr. and } \\
\text { Fishing }\end{array}$} & Chile & Schwager & 1 & 1 & Constant \\
\hline & Chile & Viconto & 1 & 1 & Constant \\
\hline & Chile & Camanchaca & & 1 & Variable \\
\hline & Chile & Corpesca & & 1 & Variable \\
\hline & Chile & Eperva & & 1 & Variable \\
\hline & Chile & Feriaosor & & 1 & Variable \\
\hline & Chile & Masisa & & 1 & Variable \\
\hline & Chile & Multifoods & & 1 & Variable \\
\hline & Chile & $\begin{array}{c}\text { Soprole } \\
\text { Inversiones S.A. }\end{array}$ & & 1 & Variable \\
\hline \multirow[t]{10}{*}{$\begin{array}{l}\text { Foods and } \\
\text { Beverages }\end{array}$} & Chile & $\begin{array}{l}\text { Concha y } \\
\text { Toro }\end{array}$ & 1 & 1 & Constant \\
\hline & Chile & Emiliana & 1 & 1 & Constant \\
\hline & Brazil & Josapar & 1 & 1 & Constant \\
\hline & Brazil & Minupar & 1 & 1 & Constant \\
\hline & Brazil & Tereos & 1 & 1 & Constant \\
\hline & Brazil & Ambev S/A & & 1 & Variable \\
\hline & Brazil & Excelsior & & 1 & Variable \\
\hline & Brazil & JBS & & 1 & Variable \\
\hline & Brazil & Minerva & & 1 & Variable \\
\hline & Brazil & Oderich & & 1 & Variable \\
\hline \multirow[t]{10}{*}{ Commerce } & Brazil & Battistella & 1 & 1 & Constant \\
\hline & Brazil & $\begin{array}{c}\text { BR } \\
\text { Pharma }\end{array}$ & 1 & 1 & Constant \\
\hline & Brazil & B2W Digital & & 1 & Variable \\
\hline & Brazil & Lojas Americanas & & 1 & Variable \\
\hline & Brazil & Lojas Hering & & 1 & Variable \\
\hline & Brazil & Natura & & 1 & Variable \\
\hline & Brazil & P.Acucar-Cbd & & 1 & Variable \\
\hline & Brazil & Wlm Ind Com & & 1 & Variable \\
\hline & Chile & Cencosud & & 1 & Variable \\
\hline & Chile & Falabella & & 1 & Variable \\
\hline Construction & Brazil & Azevedo & 1 & 1 & Constant \\
\hline
\end{tabular}


Paulo Nocera ALVES JUNIOR et al.

Table 4. Cont. ...

\begin{tabular}{|c|c|c|c|c|c|}
\hline & Brazil & $\begin{array}{l}\text { Lix da } \\
\text { Cunha }\end{array}$ & 1 & 1 & Constant \\
\hline & Brazil & PDG Realt & 1 & 1 & Constant \\
\hline & Brazi & Cyrela Realt & & 1 & Variable \\
\hline & Brazi & Helbor & & 1 & Variable \\
\hline & Brazi & MRV & & 1 & Variable \\
\hline & Chile & Salfacorp & & 1 & Variable \\
\hline \multirow[t]{5}{*}{ Mining } & Chile & Pucobre & 1 & 1 & Constant \\
\hline & Chile & Soprocal & 1 & 1 & Constant \\
\hline & Chile & Sqm & 1 & 1 & Constant \\
\hline & Brazil & Magnesita SA & & 1 & Variable \\
\hline & Brazil & Vale & & 1 & Variable \\
\hline \multirow[t]{4}{*}{$\begin{array}{l}\text { Nonmetallic } \\
\text { minerals }\end{array}$} & Chile & Cementos & 1 & 1 & Constant \\
\hline & Chile & Cristales & 1 & 1 & Constant \\
\hline & Chile & Polpaico & 1 & 1 & Constant \\
\hline & Brazil & Nadir Figuei & & 1 & Variable \\
\hline \multirow[t]{6}{*}{$\begin{array}{l}\text { Paper and } \\
\text { Cellulose }\end{array}$} & Chile & $\begin{array}{l}\text { Celulosa } \\
\text { Arauco }\end{array}$ & 1 & 1 & Constant \\
\hline & Chile & CMPC & & 1 & Variable \\
\hline & Brazil & Celul Irani & 1 & 1 & Constant \\
\hline & Brazil & $\begin{array}{l}\text { Santher } \\
\text { Fab de } \\
\text { Papel Sta } \\
\text { Terezinha }\end{array}$ & 1 & 1 & Constant \\
\hline & Brazil & Klabin S/A & & 1 & Variable \\
\hline & Brazil & Suzano Papel & & 1 & Variable \\
\hline \multirow[t]{7}{*}{$\begin{array}{l}\text { Oil and } \\
\text { Gas }\end{array}$} & Chile & Gasco & 1 & 1 & Constant \\
\hline & Chile & Copec & & 1 & Variable \\
\hline & Chile & $\begin{array}{c}\text { Empresa Nacional } \\
\text { Del Petróleo }\end{array}$ & & 1 & Variable \\
\hline & Brazil & CEG & 1 & 1 & Constant \\
\hline & Brazi & Comgas & & 1 & Variable \\
\hline & Brazi & Petrobras & & 1 & Variable \\
\hline & Brazi & $\begin{array}{c}\text { Petroleo Lub do } \\
\text { Nordeste S/A }\end{array}$ & & 1 & Variable \\
\hline Chemical & Brazil & Cristal & 1 & 1 & Constant \\
\hline
\end{tabular}


INSIDER UNDERSTANDING OF COUNTRY DEVELOPMENT ...

Table 4. Cont. ...

\begin{tabular}{|c|c|c|c|c|c|}
\hline & Brazil & $\begin{array}{c}\text { Fer } \\
\text { Heringer }\end{array}$ & 1 & 1 & Constant \\
\hline & Brazil & Ultrapar & 1 & 1 & Constant \\
\hline & Brazil & Braskem & & 1 & Variable \\
\hline & Brazil & Nutriplant & & 1 & Variable \\
\hline & Chile & Edelpa & & 1 & Variable \\
\hline & Chile & Molymet & & 1 & Variable \\
\hline & Chile & Rebrisa & & 1 & Variable \\
\hline $\begin{array}{c}\text { Steel and } \\
\text { Metallurgical }\end{array}$ & Brazil & Ferbasa & 1 & 1 & Constant \\
\hline & Brazil & Iguaçu & 1 & 1 & Constant \\
\hline & Brazil & Paranapanema & 1 & 1 & Constant \\
\hline & Brazi & Fibam & & 1 & Variable \\
\hline & Brazi & Gerdau & & 1 & Variable \\
\hline & Brazi & Gerdau Met & & 1 & Variable \\
\hline & Brazi & Haga S/A & & 1 & Variable \\
\hline & Brazi & Mangels Indl & & 1 & Variable \\
\hline & Chile & Nibsa & & 1 & Variable \\
\hline & & & &
\end{tabular}




\section{Appendix B}

Table 5. Descriptive statistics of the data for the proposed model (data in thousands dollars)

\begin{tabular}{|c|c|c|c|c|c|}
\hline & Sector & Mean & $\begin{array}{l}\text { Standard- } \\
\text { Deviation }\end{array}$ & Max & Min \\
\hline \multirow[t]{10}{*}{ COGS } & $\begin{array}{l}\text { Agr. and } \\
\text { fishing }\end{array}$ & 157702.85 & 202252.68 & 1243746.00 & 714.00 \\
\hline & $\begin{array}{l}\text { Foods and } \\
\text { beverages }\end{array}$ & 1882181.61 & 4971153.28 & 38324052.03 & 5300.82 \\
\hline & Commerce & 1507385.46 & 2888969.20 & 18289285.45 & 75.59 \\
\hline & Construction & 489823.17 & 522935.76 & 2710093.83 & 88.51 \\
\hline & Mining & 2911417.50 & 5890529.96 & 25445257.65 & 3504.51 \\
\hline & $\begin{array}{c}\text { Nonmetallic } \\
\text { minerals }\end{array}$ & 140758.56 & 86716.74 & 440008.83 & 20579.11 \\
\hline & $\begin{array}{l}\text { Paper and } \\
\text { cellulose }\end{array}$ & 1111264.72 & 1034954.88 & 3948911.00 & 38519.77 \\
\hline & Oil and gas & 8344502.65 & 19373349.84 & 102995903.59 & 710.05 \\
\hline & Chemical & 2310268.79 & 5080797.39 & 24368583.31 & 1430.77 \\
\hline & $\begin{array}{c}\text { Steel and } \\
\text { metallurgical }\end{array}$ & 1221072.80 & 2801753.72 & 16263323.71 & 1149.12 \\
\hline \multirow[t]{10}{*}{$\mathrm{CEF}$} & $\begin{array}{l}\text { Agr. and } \\
\text { fishing }\end{array}$ & 65413.97 & 70731.65 & 277243.00 & 82.82 \\
\hline & $\begin{array}{l}\text { Foods and } \\
\text { beverages }\end{array}$ & 426368.30 & 695489.63 & 3529439.00 & 1435.73 \\
\hline & Commerce & 455225.25 & 651019.79 & 3166640.30 & 35.09 \\
\hline & Construction & 534439.77 & 479079.67 & 2229064.90 & 85.83 \\
\hline & Mining & 1201196.41 & 1847880.22 & 5613289.99 & 1530.37 \\
\hline & $\begin{array}{c}\text { Nonmetallic } \\
\text { minerals }\end{array}$ & 69747.55 & 43431.77 & 220326.89 & 23431.87 \\
\hline & $\begin{array}{c}\text { Paper and } \\
\text { cellulose }\end{array}$ & 459882.90 & 374080.41 & 1111044.00 & 17214.45 \\
\hline & Oil and gas & 1821768.16 & 4272109.80 & 16984335.98 & 204.11 \\
\hline & Chemical & 330323.05 & 571408.91 & 2452962.44 & 151.35 \\
\hline & $\begin{array}{c}\text { Steel and } \\
\text { metallurgical }\end{array}$ & 596219.28 & 1131265.18 & 4633466.58 & 1131.32 \\
\hline \multirow[t]{2}{*}{ CEI } & $\begin{array}{l}\text { Agr. and } \\
\text { fishing }\end{array}$ & 64440.62 & 70448.94 & 277243.00 & 82.82 \\
\hline & $\begin{array}{l}\text { Foods and } \\
\text { beverages }\end{array}$ & 427246.67 & 695298.40 & 3529439.00 & 1435.73 \\
\hline
\end{tabular}


Table 5. Cont. ...

\begin{tabular}{|c|c|c|c|c|c|}
\hline & Commerce & 454515.63 & 651219.03 & 3166640.30 & 35.09 \\
\hline & Construction & 547631.70 & 497264.48 & 2229064.90 & 85.83 \\
\hline & Mining & 1205008.72 & 1860015.24 & 5613289.99 & 1530.37 \\
\hline & $\begin{array}{c}\text { Nonmetallic } \\
\text { minerals }\end{array}$ & 70886.62 & 44120.38 & 220326.89 & 23802.94 \\
\hline & $\begin{array}{l}\text { Paper and } \\
\text { cellulose }\end{array}$ & 459035.94 & 371421.15 & 1111044.00 & 17214.45 \\
\hline & Oil and gas & 1843672.29 & 4309151.04 & 16984335.98 & 204.11 \\
\hline & Chemical & 332502.20 & 574562.51 & 2452962.44 & 151.35 \\
\hline & $\begin{array}{c}\text { Steel and } \\
\text { metallurgical }\end{array}$ & 614870.11 & 1156605.80 & 4633466.58 & 1131.32 \\
\hline \multirow[t]{10}{*}{ CPP } & $\begin{array}{l}\text { Agr. and } \\
\text { fishing }\end{array}$ & 158676.20 & 199595.28 & 1235085.00 & 639.00 \\
\hline & $\begin{array}{l}\text { Foods and } \\
\text { beverages }\end{array}$ & 1881303.23 & 4956929.49 & 37909254.24 & 2886.06 \\
\hline & Commerce & 1508095.07 & 2892310.62 & 18430587.06 & 77.59 \\
\hline & Construction & 476631.24 & 504156.64 & 2672333.75 & 97.00 \\
\hline & Mining & 2907605.19 & 5844013.43 & 25356996.11 & 3405.36 \\
\hline & $\begin{array}{c}\text { Nonmetallic } \\
\text { minerals }\end{array}$ & 139619.48 & 84026.14 & 434306.24 & 24574.29 \\
\hline & $\begin{array}{l}\text { Paper and } \\
\text { cellulose }\end{array}$ & 1112111.68 & 1027517.14 & 3919921.00 & 36919.04 \\
\hline & Oil and gas & 8322598.52 & 19236239.48 & 102598251.13 & 751.98 \\
\hline & Chemical & 2308089.64 & 5072284.12 & 24374236.67 & 1326.75 \\
\hline & $\begin{array}{c}\text { Steel and } \\
\text { metallurgical }\end{array}$ & 1202421.96 & 2768952.08 & 16213962.45 & 1309.96 \\
\hline
\end{tabular}

